Vol. 2 No. 2 Juli 2020

\title{
PENERAPAN TATA KELOLA PERUSAHAAN YANG BAIK (GOOD \\ CORPORATE GOVERNANCE) DI BIDANG PENGAMANAN ASSET \\ UNTUK MEMINIMALISIR PENCURIAN TANDAN BUAH SEGAR (TBS) KELAPA SAWIT DI PTPN IV
}

\author{
Junaedi, Bismar Nasution, Sunarmi, Mahmul Siregar \\ bintang.lyatiara66@gmail.com, bismarnasution@gmail.com, sunarmi@usu.ac.id, \\ mahmuls@yahoo.co.id \\ DOI 10.34010/rnlj.v2i2.3329
}

\begin{abstract}
.
A good company is a company that guarantees the welfare of its employees, on the contrary, good employees must also have a sense of belonging and high loyalty to the company where they work. PT. Perkebunan Nusantara IV (Persero) is a State-Owned Enterprise (SOE) in the form of a Limited Liability Company (PT) (hereinafter referred to as PTPN IV). In the context of stateowned PT, a good state-owned PT is a state-owned PT that can contribute to stakeholders to ensure public welfare. The instrument for PTPN IV to contribute to stakeholders in order to ensure the realization of public welfare is the implementation of Good Corporate Governance (GCG). In addition, in implementing GCG it is also necessary to apply Good Corporate Culture (GCC) because GCG and GCC have a very close relationship. GCG is the visible side of the company, while the GCC is the inside side of the company or the value side of corporate management. Assets with a total value of more than Rp. 14 trillion must be secured for the sustainability and sustainability of the company's business wheels. The safeguarding of these assets must start from the smallest, an example in this study is the security of oil palm Fresh Fruit Bunches (FFB) which are often stolen, both by "ninja", and "mafias". Various modes of crime surfaced, such as theft of FFB; trimming FFB; land grabbing; employee abuse; darkening of the core \& Crude Palm Oil (CPO); and employee mistreatment. One of the breakthroughs in implementing GCG that will be implemented at PTPN IV to secure assets to minimize the theft of oil palm FFB is the application of technology, information, and communication at PTPN IV in the form of an application system "Smart Security of Integrity".
\end{abstract}

Keywords. Good Corporate Governance; Asset Security; and PTPN IV Palm Oil Theft.

\section{PENDAHULUAN \\ Latar Belakang}

PTPN IV sebagai anak usaha BUMN yang berbadan hukum Perseroan Terbatas (PT) dan bergerak dalam bidang agroindustri perkebunan kelapa sawit mempunyai peranan yang sangat penting dan potensial guna memberikan konstribusi kepada Negara dalam pembangunan. Oleh karenanya, PTPN IV diharapkan mampu memberikan kontribusi kepada pemangku kepentingan demi kesejahteraan umum.

Adapun instrumen bagi PTPN IV untuk memberikan kontribusi kepada stakeholders (pemangku kepentingan) guna menjamin terwujudnya kesejahteraan umum adalah dengan diterapkannya good corporate governance (GCG). Selain itu, dalam penerapan GCG perlu juga menerapkan good corporate culture (GCC) karena GCG dengan GCC mempunyai hubungan yang sangatlah erat. Dapat dikatakan bahwa GCG merupakan sisi yang tampak dari perusahaan, yang dapat dilihat dari nilai-nilai pokok yang dirumuskan Forum GCG Indonesia tentang GCG, yaitu TIARF (transparency; 
Vol. 2 No. 2 Juli 2020

independency; accountability; responsibility; dan fairness). Sementara, good corporate culture merupakan sisi dalam, atau sisi nilai dari pengelolaan perusahaan (value). Dengan kata lain, GCC menjadi bagian hulu dari GCG dengan muatannya yang fokus pada basic value (nilai-nilai dasar) dari pengelolaan perusahaan yang kemudian diturunkan melalui sistem. ${ }^{1}$

Good corporate culture merupakan "inti" dari organisasi perusahaan. Dapat pula dikatakan sebagai roh atau jiwa dari suatu lembaga. Lebih fokus lagi, GCC merupakan inti dari GCG. Hal ini sesuai dengan pendapat Cartwright bahwa budaya perusahaan adalah "a powerful determinant of people's beliefs, attitudes, and behaviour". Budaya perusahaan yang baik atau good corporate culture menjadi determinan dari tata kelola perusahaan yang baik (good corporate governance). Terbentuk dan berkembangnya manajemen profesional, kuatnya komitmen tanggung jawab sosial dari perusahaan terhadap lingkungannya, dan semangat untuk menjaga keunggulan korporasi. ${ }^{2}$

Dewasa ini banyak ditemukan pencurian yang terjadi di seluruh aspek ruang lingkup, terlebih khusunya pada ruang lingkup perkebunan. Hal ini dikarenakan perkebunan merupakan bidang usaha yang memliki banyak aset berharga, ditambah lagi dengan komoditi perkebunan seperti kelapa sawit yang di masa sekarang ini perkembangannya semakin pesat, sedangkan masyarakat yang ada disekitar perkebunan tidak ikut merasakan dampak kesejahteraan dari perkebunan yang berdiri di tengahtengah masyarakat. Ini merupakan faktor daya tarik masyarakat untuk dapat memiliki aset-aset perkebunan dengan cara-cara kriminal. ${ }^{3}$

Dalam kaitannya dengan penelitian ini, bahwasanya terdapat permasalahan yang harus diselesaikan di dalam PTPN IV, yaitu: terkait dengan adanya pencurian-pencurian Tandan Buah Segar (TBS) kelapa sawit pada setiap kebun. Sebagaimana diketahui bahwasanya PTPN IV bergerak dalam bidang usaha perkebunan kelapa sawit. Saat ini usaha kebun kelapa sawit yang dimiliki PTPN IV sebagai perpanjangan tangan negara untuk meningkatkan kesejahteraan masyarakat ada sebanyak 30 (tiga puluh) unit usaha. Selain itu, juga terdapat 1 (satu) unit usaha perkebunan teh, 1 (satu) unit usaha kebun plasma kelapa sawit, dan 1 (satu) unit usaha perbengkelan. ${ }^{4}$

Perusahaan sekelas PTPN IV yang menyandang status anak usaha BUMN yang mempunyai total aset per Desember 2017 sebesar Rp. 14,61 triliun, terdiri dari : aset lancar sebesar Rp. 1,86 triliun dan aset tidak lancar Rp. 12,75 trilun, tidak terlepas dari permasalahan-permasalahan hukum yang dihadapi. ${ }^{5}$ Aset dengan nilai total lebih dari Rp.

1 Djokosantoso Moeljono, Good Corporate Culture Sebagai Inti Good Corporate Governance, (Jakarta : Elex Media Komputindo, 2005), hlm. 74.

${ }^{2}$ Ibid., hlm. 75

3 Warman, Edi., "Analisis Yuridis Mengenai Tindak Pidana Pencurian Aset Perkebunan PTPN II Kebun Tanjung Garbus-Pagar Merbau Lubuk Pakam Dalam Perspektif Kriminologi”, Jurnal Mahupiki Vol. 2 No. 1, (2014) 2018, hlm. 97.

4 PT. Perkebunan Nusantara IV, "Laporan Tahunan 2017" , PT. Perkebunan Nusantara IV, Medan,

5 PTPN IV yang menyandang status anak usaha BUMN adalah sejak bergabungnya PTPN IV kepada PTPN III yang merupakan holding BUMN Perkebunan Nusantara, sehingga PTPN IV menjadi anak usaha PTPN 
Fakultas Hukum Universitas Komputer Indonesia

Vol. 2 No. 2 Juli 2020

14 triliun tersebut harus diamankan guna keberlangsungan dan keberlanjutan roda usaha perusahaan. Pengamanan aset tersebut harus dimulai dari yang terkecil, contoh dalam penelitian ini adalah pengamanan Tandan Buah Segar (TBS) kelapa sawit yang sering dicuri, baik oleh ninja sawit, maupun mafia-mafia sawit. Berbagai modus kejahatan muncul ke permukaan, seperti: pencurian TBS; pemangkasan TBS; perampasan lahan; penganiayaan karyawan; penggelapan inti \& Crude Palm Oil (CPO); dan penganiayaan karyawan. ${ }^{6}$

Adapun fakta temuan di lapangan modus kejahatan perkebunan bersifat masif dan terorganisir. Terhadap pencurian sawit, banyak anggapan masyarakat sering dilakukan oleh ninja sawit (kejahatan sederhana), namun kenyataannya pencurian oleh "ninja sawit" hanya sekitar $10 \%$ s.d. $15 \%$ saja. Dalam kenyataannya, ada mafia sawit beroperasi di kebun-kebun PTPN IV yang menampung dari pencuri-pencuri sawit tersebut hingga $85 \%$ s.d. 90\% (kejahatan terorganisir/serius). Mafia-mafia sawit tersebut, terdiri dari : penampung, Organisasi Kepemudaan (OKP), Lembaga Swadaya Masyarakat (LSM); RAMP; PKS tanpa kebun; aktor intelektual; pemodal; bandar narkoba; oknumoknum karyawan nakal; dan beking. Lemahnya sistem pengamanan dan penegakan hukum serta minimnya koordinasi dengan Aparat Penegak Hukum menjadi alasan terjadinya pencurian dan penggelapan TBS tersebut. ${ }^{7}$

Tindak pidana pencurian dan penggelapan TBS kelapa sawit di area PTPN IV ini bersifat masif dan dapat dikategorikan sangat genting (state of civil emergency). Pencurian dan penggelapan TBS kelapa sawit ini dapat diibaratkan sebagai penyakit kanker stadium IV yang sudah menjalar pada setiap organ penting. Adapun perkiraan nilai kerugian yang diderita PTPN IV adalah sebesar + Rp. 500 miliar / tahun, padahal perusahaan telah mengeluarkan biaya pengamanan sebesar + Rp. 130 miliar / tahun dengan jumlah tenaga kerja keamanan berjumlah +2.200 personil. ${ }^{8}$ Selain itu, kurangnya penegakan hukum sehingga mengakibatkan kurangnya efek jera terhadap pelaku kejahatan dikarenakan penerapan sanksi pidana dalam Undang-Undang No. 39 Tahun 2014 tentang Perkebunan masih minim.

Adapun salah satu terobosan penerapan GCG yang akan dilaksanakan pada PTPN IV untuk mengamankan aset guna meminimalisir pencurian TBS kelapa sawit adalah penerapan teknologi, informasi, dan komunikasi di PTPN IV dalam bentuk sistem aplikasi "Smart Security of Integrity". Adapun gambar proses sistem Smart Security of Integrity, dapat dilihat di bawah ini :

III dan PTPN III menjadi induk usahanya. Lihat : Peraturan Pemerintah RI No. 72 Tahun 2014 tentang Penambahan Penyertaan Modal Negara Republik Indonesia ke Dalam Modal Saham Perusahaan Perseroan (Persero) PT. Perkebunan Nusantara III.

${ }^{6}$ Ibid.

7 Laporan No. TBL/937/XII/2017 Bareskrim, tertanggal o8 Desember 2017 tentang Pelaporan Dugaan Tindak Pidana Memanen atau Memungut Hasil Perkebunan Secara Tidak Sah sebagaimana dimaksud dalam Pasal 107 hruuf d Undang-Undang No. 39 Tahun 2014 tentang Perkebunan Jo. Pasal 55 KUH.Pidana.

${ }^{8}$ Angka perkiraan kerugian PTPN IV terhadap pencurian TBS Kelapa Sawit. 


\section{Res Nullius}

\section{Gambar 1}

Proses Sistem Smart Security of Integrity

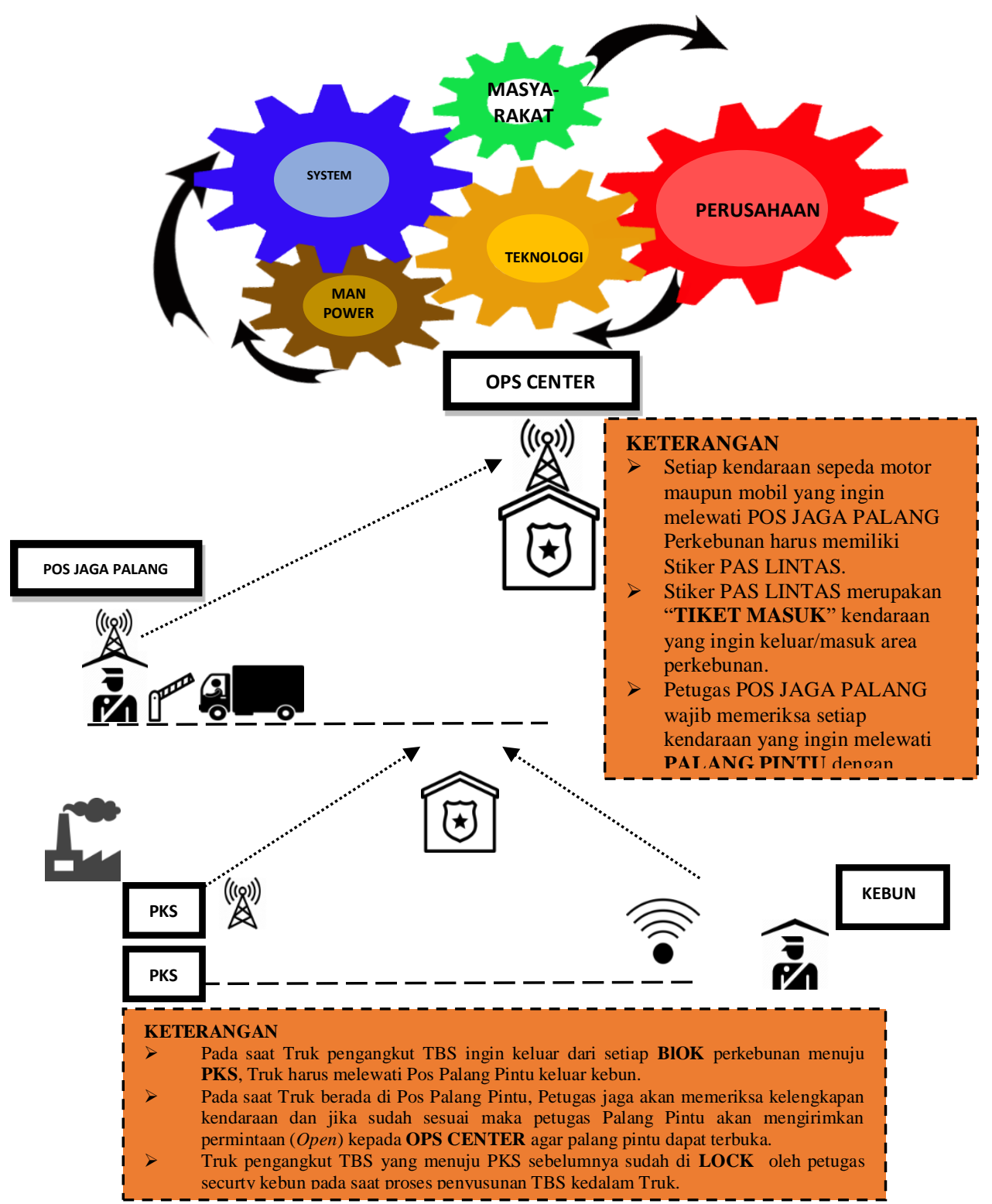

Sumber : Data Sekunder Yang Diolah, PTPN. IV Tahun 2018.

Berdasarkan gambar tersebut di atas, sistem aplikasi Smart Security of Integrity akan memberikan informasi secara otomatis kepada Satuan Pengamanan apabila terdapat orang-orang yang akan atau sudah mencuri TBS kelapa sawit tersebut. Penelitian ini diharapkan dapat menyelesaikan permasalahan-permasalahan genting tersebut dengan menerapkan good corporate governance (GCG) pada PTPN IV dalam bidang pengamanan aset diharapkan minimal dapat mengurangi kejahatan pencurian dan penggelapan TBS kelapa sawit di PTPN IV. Persoalannya adalah good corporate governance (GCG) yang bagaimana dapat mengamankan aset guna meminimalisir 
Fakultas Hukum Universitas Komputer Indonesia

Vol. 2 No. 2 Juli 2020

pencurian TBS kelapa sawit di PTPN IV; apakah dengan dilaksanakannya program kebun plasma dan Program Kemitraan Bina Lingkungan (PKBL) sebagai wujud dari pelaksanaan tanggung jawab sosial dan lingkungan (TJSL) atau corporate social responsibility (CSR) sebagai perintah/mandat Pasal 74 UU Perseroan Terbatas dapat mengamankan aset milik PTPN IV dan meminimalisir pencurian TBS kelapa sawit yang sudah mengakar terjadi di lapangan. Permasalahan-permasalahan seperti hal yang demikian perlu untuk dilakukan penelitian.

Berdasarkan uraian-uraian tersebut di atas, maka penelitian berjudul : "Penerapan Tata Kelola Perusahaan Yang Baik (Good Corporate Governance) di Bidang Pengamanan Aset Untuk Meminimalisir Pencurian Tandan Buah Segar (TBS) Kelapa Sawit di PT. Perkebunan Nusantara IV", layak untuk dikaji dan dianalisis lebih lanjut.

\section{Rumusan Masalah}

Berdasarkan uraian latar belakang tersebut di atas, maka rumusan masalah dalam penelitian, sebagai berikut :

1. Bagaimana penerapan tata kelola perusahaan yang baik (good corporate governance) dalam bidang pengamanan aset untuk meminimalisir pencurian Tandan Buah Segar (TBS) kelapa sawit di PT. Perkebunan Nusantara IV?

2. Bagaimana hambatan yang dihadapi PT. Perkebunan Nusantara IV dalam penerapan good corporate governance (GCG) dalam bidang pengamanan aset untuk meminimalkan pencurian TBS kelapa sawit pada kebun-kebun PT. Perkebunan Nusantara IV dan upaya yang telah dilakukan?

\section{Tujuan Penelitian}

Adapun tujuan penelitian ini adalah sebagai berikut :

1. Untuk mengkaji dan menganalisis penerapan tata kelola perusahaan yang baik (good corporate governance) dalam bidang pengamanan aset untuk meminimalisir pencurian Tandan Buah Segar (TBS) kelapa sawit di PT. Perkebunan Nusantara IV.

2. Untuk mengkaji dan menganalisis hambatan yang dihadapi PT. Perkebunan Nusantara IV dalam penerapan good corporate governance (GCG) dalam bidang pengamanan aset untuk meminimalkan pencurian TBS kelapa sawit pada kebunkebun PT. Perkebunan Nusantara IV dan upaya yang telah dilakukan.

\section{KERANGKA TEORI}

\section{Stakeholders Theory of Modern Corporation}

Kewajiban dasar manajemen perusahaan bukanlah untuk memaksimalkan keberhasilan keuangan perusahaan, tetapi untuk memastikan kelangsungan hidupnya dan menyeimbangkan tuntutan yang saling bertentangan dari berbagai pemangku 
Fakultas Hukum Universitas Komputer Indonesia

Vol. 2 No. 2 Juli 2020

kepentingan. Pengurus perusahaan (eksekutif) harus diberitahu oleh hukum untuk mengelola perusahaan demi kepentingan stakeholders. ${ }^{9}$

Pokok ajaran R. Edward Freeman tentang "A Stakeholder Theory of The Modern Corporation", yaitu:

1. "Bahwa manajer perusahaan memiliki tugas kepada semua kelompokkelompok dan individu yang memiliki saham (a stake) dalam atau klaim pada perusahaan (Freeman menyebut kelompok-kelompok dan individu ini sebagai 'stakeholder'); ${ }^{10}$

2. Bahwa tidak ada kelompok stakeholder yang harus diberikan keutamaan atas yang lainnya ketika perusahaan menengahi klaim persaingan stakeholder; dan

3. Bahwa hukum perusahaan harus diubah sehingga membutuhkan eksekutif untuk mengelola perusahaan mereka sesuai dengan prinsip-prinsip dari teori pemangku kepentingan (stakeholder), yaitu, Freeman menyatakan bahwa eksekutif $^{11}$ harus diberitahu (secara hukum/resmi) untuk mengelola perusahaan mereka untuk kepentingan stakeholders mereka". ${ }^{12}$

Teori pemangku kepentingan pada korporasi modern (stakeholder theory of the modern corporation) merupakan teori yang cukup dikenal dalam dunia hukum korporasi. Dengan semakin pentingnya peran dan kedudukan seluruh pemangku kepentingan (stakeholders) dalam pengelolaan perusahaan, memunculkan pemikiran kedua yang sangat bertolak belakang dengan pandangan dalam tersebut. ${ }^{13}$ Pandangan kedua ini (" $A$

9 Milton Snoeyenbos, Robert Almeder, James Humber, Business Ethics, $3^{\text {th }}$ Ed., dalam Bismar Nasution, Disampaikan pada Lokakarya Nasional Federasi Serikat Perkerja Perkebunan Nusantara, "Mau Dibawa Kemana Holding BUMN Perkebunan, diselenggarakan Federasi Serikat Pekerja Perkebunan Nusantara, Jakarta, tanggal 21 Pebruari 2019.

10 Richard Smerden, "A Practical Guide to Corporation Governance Fourth Edition", (London: Thomson Reuters (Legal) Limited, 2010", hlm. 3. Bandingkan : Leonard J. Theberge, "Law and Economic Development", Journal of International Law and Policy, (Vol.9:231). Para stakeholder merujuk pada orangorang dan kelompok yang mempengaruhi, atau dipengaruhi oleh keputusan organisasi, kebijakan, dan operasi. Kata Stake, dalam konteks ini, berarti minat dalam-atau klaim atas-perusahaan bisnis. Mereka dengan keterkaitan dalam tindakan perusahaan mencakup beragam kelompok seperti pelanggan, karyawan, pemegang saham, media, pemerintah, asosiasi profesional dan perdagangan, aktivis sosial dan lingkungan, dan organisasi non pemerintah.

Lihat juga : The Term Stakeholder Was First Introduces in 1963 but was not widely used in the management literature until the publication of R. Edward Freeman's strategic Management: A Stakeholder Approach (Marshfield, MA : Pitman, 1984). For more recent summaries of the stakeholder theory literature. Lihat : Thomas Donaldson and Lee E.Preston, "The Stakeholder Theory of the Corporation: Concepts, Evidence, Implications", Academy of Management Review, January 1995, pp.71-83; Max B.E. Clarkson, ed. The Corporation and Its Stakeholders: Classic and Contemprorary Readings (Toronto : University of Toronto Press, 1998); and Abe J.Zakhem, Daniel E. Palmer, and Mary Lyn Stoll, Stakeholder Theory: Essential Readings in Ethical Leadership and Management (Amherst, NY : Prometheus Books, 2008).

${ }^{11}$ See: Three ways in which agents may differ from their principals. First, the agents may have different preferences from their principal, such as willingness to work. Second, agents may have different incentives from the principal. Agents may have a different stake in the outcome or may receive different rewards than the principal. Third, agents may have information that is unavailable to the principal, or vice versa. These types of divergences may give rise to problems relating to monitoring, incentives, coordination, and strategy. (Michael L. Moffitt dan Robert C. Bordone, eds., Handbook of Dispute Resolution [Program on Negotiation/Jossey-Bass, 2005], p. 190.

${ }_{12}$ Milton Snoeyenbos, et.al., Op.cit., hlm. 62.

${ }_{13}$ Pandangan pertama maksudnya disini adalah pendapat Milton Friedman yang dimuat dalam New York Times Magazine tanggal 13 September 1970, dengan judul: "The Social Responsibility of Business is to Increase its Profits", yang menyatakan bahwa: "Satu-satunya tanggungjawab perusahaan adalah meningkatkan keuntungan sampai menjadi sebesar mungkin. Tanggungjawab ini diletakkan dalam tangan para manajer. Para manajer hanya menjalankan tugas yang dipercayakan kepada mereka oleh para pemegang saham sebagai 
Vol. 2 No. 2 Juli 2020

Stakeholder Theory of the Modern Corporation"), mengakui eksistensi tanggungjawab sosial perusahaan terhadap para pemangku kepentingan (stakeholders). Toeri " $a$ stakeholder theory of the modern corporation" menawarkan alternatif dari teori Friedman. Pada tampilan Freeman, Friedman salah mengasumsikan bahwa tugas utama moral eksekutif perusahaan adalah masalah fidusia ${ }^{14}$ terhadap pemegang saham mereka dan bahwa dalam memenuhi kewajiban ini mereka bertindak secara bertanggung jawab sosial. Freeman berbeda pendapat dengan Friedman.

Terlepas dari apakah manajemen pemangku kepentingan mengarah pada kinerja keuangan membaik, manajer harus mengelola bisnis untuk kepentingan semua stakeholder. Ini memandang perusahaan bukan sebagai mekanisme untuk meningkatkan pengembalian keuangan stockholders, ${ }^{15}$ tetapi sebagai kendaraan kepentingan koordinasi stakeholder dan melihat manajemen sebagai memiliki hubungan fidusia tidak hanya untuk para pemegang saham, tetapi untuk semua stakeholder.

Menurut teori normatif stakeholder, manajemen harus memberikan pertimbangan sama dengan kepentingan semua stakeholder, ketika konflik kepentingan, mengelola bisnis sehingga untuk mencapai keseimbangan optimal antara mereka. Ini, tentu saja, menyiratkan bahwa akan ada waktu ketika manajemen wajib untuk setidaknya sebagian mengorbankan kepentingan stockholders untuk orang-orang dari pemangku kepentingan lainnya (stakeholders). ${ }^{16}$ Sejalan dengan pemikiran tersebut, John Hasnas menyatakan bahwa: "management's fundamental obligation is not to maximize the firm's financial success, but to ensure its survival ${ }^{17}$ by balancing the conflicting claims of multiple stakeholders". ${ }^{18}$

pemilik perusahaan. Modal milik pribadi boleh saja dipakai untuk tujuan-tujuan sosial, tetapi jika manajer memakai modal perusahaan untuk itu, ia merugikan para pemilik modal. Jadi tanggungjawab sosial boleh saja dijalankan oleh para manajer secara pribadi seperti juga oleh semua orang lain, tetapi sebagai manajer perusahaan mereka mewakilli para pemegang saham dan karena itu tanggungjawab mereka adalah mengutamakan kepentingan para pemegang saham yakni memperoleh keuntungan sebanyak mungkin". Lihat: Milton Friedman, "The Social Responsibility of Business is to Increase its Profits", The New York Times Magazine, tanggal 13 September 1970. Dengan kata lain, pandangan pertama merupakan pandangan yang berpendapat bahwa perusahaan diciptakan untuk mencari keuntungan sebesar-besarnya demi kepentingan pemegang saham (shareholders).

Pemikiran ini didukung oleh Joel Bakan yang mengajarkan bahwasanya jika perusahaan memberikan sebahagian keuntungannya kepada masyarakat, maka perusahaan tersebut telah menyalahi kodratnya. Lihat: K. Bartens, Pengantar Etika Bisnis, (Yogyakarta: Kanisius, 2002), hlm. 294. Pemikiran-pemikiran Milton Friedman, Joel Bakan dan ahli-ahli ekonmi dan sosial pada era kejayaan kapitalisme klasik, mendukung tegaknya prinsip duty to act bonafide in the interest of the company yang dikenal luas dalam hukum perseroan yang menuntut kewajiban direksi agar mengelola perseroan untuk kepentingan dan keuntungan perseroan. Tentunya tujuan akhirnya adalah untuk memaksimalkannilai (value) bagi para pemegang saham. Lihat juga: Philip Lipton dan Abraham Herzberg, Understanding Company Law, (Brisbane: The Law Book Company Ltd., 1992), hlm. 297.

14 Fidusia menurut asal katanya berasal dari bahasa Romawi "fides", yang berarti kepercayaan. Fidusia merupakan istilah yang sudah lama dikenal dalam bahasa Indoensia. Begitu pula istilah ini digunakan dalam Undang-Undang No. 42 Tahun 1999 tentang Jaminan Fidusia. Pasal 1 angka 1, "fidusia" yaitu pengalihan hak kepemilikan suatu benda atas dasar kepercayaan dengan ketentuanbahwa benda yang hak kepemilikannya dialihkan tetap dalam penguasaan pemilik benda.

${ }_{15} \mathrm{~A}$ shareholder or stockholder is an individual or institution (including a corporation) that legally owns a share of stock in public or private corporation. Shareholders are the owners of a limited company. They buy shares which represent part ownership of a company.

${ }_{16}$ John Hasnas, The Normative Theories of Business Ethics A Guide for Perplexed, dalam Abe J. Zakem, Daniel E. Palmer, dan Mary Lyn Stoll (ed.), Stakeholder Theory, (New York: Promethus Books, 2008), hlm. 118 .

${ }_{17}$ Bandingkan: Teori Darwinisme, The Survival of The Fittest - "Survival of the Fittest" is a phrase that originated in evolutionary theory as an alternative way of describing the mechanism of natural selection.

${ }^{18}$ John Hasnas, Loc.cit., hlm. 118. 
Fakultas Hukum Universitas Komputer Indonesia

Vol. 2 No. 2 Juli 2020

Menurut John Elkington dalam "Cannibal with Forks: The Triple Bottom Line Twentieth Century Business" (1997), mengatakan bahwa: "jika perusahaan ingin tetap sustain, maka ia perlu memperhatikan tidak saja kepentingan para pemegang saham (profit), tetapi juga harus memperhatikan kesejahteraan orang-orang yang berada di dalamnya dan disekitarnya (peoples) serta kelestarian lingkungan hidup (planet)". ${ }^{19}$

Teori stakeholder menyatakan bahwa kewajiban dasar manajemen bukanlah untuk memaksimalkan keberhasilan keuangan perusahaan, tetapi untuk memastikan kelangsungan hidupnya dengan menyeimbangkan tuntutan yang saling bertentangan dari berbagai pemangku kepentingan. Perusahaan harus dikelola untuk kepentingan dari para stakeholder, pelanggan, pemasok, pemilik, karyawan, dan masyarakat lokal. Hak-hak kelompok-kelompok ini harus dipastikan dan, lebih jauh, kelompok harus berpartisipasi, dalam beberapa rasa, dalam keputusan yang secara substansial mempengaruhi kesejahteraan mereka

Dengan demikian, stakeholder theory atau primacy stakeholder mempengaruhi hukum di bidang korporasi untuk mengarahkan pengelolaan korporasi kepada kepentingan para pemangku kepentingan. Teori stakeholder yang mempengaruhi hukum di bidang korporasi dikarenakan, teori " $a$ stakeholder theory of the modern corporation" percaya bahwa korporasi yang modern mempunyai kewajiban untuk memastikan kelangsungan hidupnya dengan menyeimbangkan tuntutan yang saling bertentangan dari berbagai pemangku kepentingan. Pemangku kepentingan tersebut, terdiri dari: para stakeholder, pelanggan, pemasok, pemilik, karyawan, dan masyarakat lokal.

Korporasi yang bertujuan untuk memastikan kelangsungan hidupnya dengan menyeimbangkan tuntutan para pemangku kepentingan tersebut harus dikelola dengan Good Corporate Governance (GCG). Hal ini disebabkan, menurut Forum for Corporate Governance in Indonesia (2001), menyatakan GCG adalah seperangkat peraturan yang menetapkan hubungan antara pemangku kepentingan pengurus, pihak kreditur, pemerintah, karyawan, serta para pemegang kepentingan internal dan eksternal lainnya sehubungan dengan hak-hak dan kewajiban mereka, atau dengan kata lain sistem yang mengarahkan dan mengendalikan perusahaan. ${ }^{20}$

Good Corporate Governance merupakan sebagai tata cara kelola perusahaan sehat yang sudah diperkenalkan oleh pemerintah Indonesia dan International Monetary Fund (IMF). ${ }^{21}$ Menurut The Indonesian Institute for Corporate Governance (IICG), Corporate Governance adalah serangkaian mekanisme yang mengarahkan dan

19 Hennigfeld Judith, The ICCA Handbook on Corporate Social Responsibility, (John Wiley \& Sons, 2006), hlm. 27.

${ }^{20}$ Forum for Corporate Governance in Indonesia. Seri Tata Kelola (Corporate Governance) Jilid II, 2001.

${ }^{21}$ Indonesia mulai menerapkan prinsip GCG sejak menandatangani Letter of Intent (L.o.I) dengan IMF, yang salah satu bagian pentingnya adalah pencantuman jadwal perbaikan pengelolaan perusahaanperusahaan di Indonesia. Sejalan dengan hal tersebut, Komite Nasional Kebijakan Corporate Governance (KNKCG) berpendapat bahwa perusahaan-perusahaan di Indonesia mempunyai tanggung jawab untuk menerapkan standar GCG yang telah diterapkan di tingkat internasional. Lihat: Asmaji Darmawi, Antologi Administrasi Publik \& Pembangunan: Festschrift untuk Sjamsiar Sjamsuddin, Cet. Ke-1, (Malang: UB Press, 2016), hlm. 243. 
Vol. 2 No. 2 Juli 2020

mengendalikan suatu perusahaan agar operasional perusahaan berjalan sesuai dengan harapan para pemangku kepentingan (stakeholders). ${ }^{22}$

Corporate Governance adalah rangkaian proses terstruktur yang digunakan untuk mengelola serta mengarahkan atau memimpin bisnis dan usaha-usaha korporasi dengan tujuan untuk meningkatkan nilai-nilai perusahaan serta kontinuitas usaha. good corporate governance merupakan struktur, sistem, dan proses yang digunakan oleh organ-organ perusahaan sebagai upaya untuk memberi nilai tambah perusahaan secara berkesinambungan dalam jangka panjang, dengan tetap memperhatikan kepentingan stakeholder lainnya, berlandaskan moral, etika, budaya dan aturan berlaku lainnya.

Peristilahan good corporate governance muncul pada akhir tahun 1980-an yang diperkenalkan oleh Cadbury Committee dalam suatu laporan yang dikenal dengan Cadbury Report. ${ }^{23}$ Kata governance diartikan sebagai the activity or manner of goverring, sedangkan arti dari goverring sebagai having the power or right to govern. ${ }^{24}$

Good corporate governance diartikan sebagai sebuah perusahaan yang telah dikelola secara baik dan benar dan didasarkan pada prinsip-prinsip fairness, accountability, responsibility, transparency. Dengan prinsip ini nilai perusahaan dalam jangka panjang akan naik tanpa mengabaikan kepentingan stakeholder yang lain. Pemberlakuan prinsip good corporate governance merupakan langkah penting membangun dan memulihkan kepercayaan publik terhadap perusahaan. ${ }^{25}$

Menurut Bank Dunia (World Bank), good corporate governance adalah kumpulan hukum, peraturan dan kaidah-kaidah yang wajib dipenuhi yang dapat mendorong kinerja sumber-sumber perusahaan bekerja secara efisien, menghasilkan nilai ekonomi jangka panjang yang berkesinambungan bagi para pemegang saham maupun masyarakat sekitar secara keseluruhan.

Berikut definisi dan pengertian good corporate governance dari beberapa literatur:

a. Menurut Tunggal (2013), good corporate governance adalah sistem yang mengatur, mengelola dan mengawasi proses pengendalian usaha untuk menaikkan nilai saham, sekaligus sebagai bentuk perhatian kepada stakeholders, karyawan dan masyarakat sekitar. ${ }^{26}$

b. Menurut Agoes (2011), good corporate governance adalah suatu sistem yang mengatur hubungan peran Dewan Komisaris peran Direksi, pemegang saham, dan pemangku kepentingan lainnya. Tata kelola perusahaan yang baik

39 Fadillah Abdi Widodo, "Peran Corporate Governance Perception Index Serta Ukuran Perusahaan Terhadap Kinerja Keuangan Perusahaan Pada Hasil Survei The Indonesian Institute for Corporate Governance (IICG) Periode 2010-2012", Program Studi Akuntansi Universitas Dian Nuswantoro, Semarang, http://eprints.dinus.ac.id/17096/1/jurnal_15420.pdf., diakses pada hari Sabtu, 20 Juni 2020.

${ }_{23}$ Tan kamello, dalam Sri Suyono, Perlindungan Hukum Terhadap Karyawan Dalam Rancangan Merger Diantara BUMN), Program Pascasarjana Universitas Sumatera Utara, Medan, 2003.

24 Jonatahan Crowter (ed), Good Corporate Governance .Oxford Advanced Learners Dictionary, (New York : Oxford University Press, 1995), hlm. 515

25 Bactiar Hassan Miraza, Good Corporate Governance" Makalah disampaikan pada lokakarya Good Corpore Governance, kerjasama Program Pascasarjana Universitas Sumatera Utara, Program Pascasarjana Universitas Indonesia, Universitas of South Carolina, Bursa Efek Jakarta dan Bapepam, Medan, 2000.

${ }^{26}$ A. Wijaya Tunggal, Internal Audit dan Good Corporate Governance, (Jakarta: Erlangga, 2013). 
Vol. 2 No. 2 Juli 2020

juga disebut sebagai proses yang transparan atas penentuan tujuan perusahaan, pencapainya dan penilaian kinerjanya. ${ }^{27}$

c. Menurut Kusmastuti (2008), good corporate governance merupakan sistem tata kelola yang diselenggarakan dengan mempertimbangkan semua faktor yang mempengaruhi proses institusional, termasuk faktor-faktor yang berkaitan dengan regulator. ${ }^{28}$

d. Menurut Sutedi (2011), good corporate governance adalah suatu proses dan struktur yang digunakan oleh organ perusahaan (pemegang saham/pemilik modal, komisaris, dewan pengawas dan direksi) untuk meningkatkan keberhasilan usaha dan akuntabilitas perusahaan guna mewujudkan nilai pemegang saham dalam jangka panjang dengan tetap memperhatikan kepentingan stakeholder lainnya, berlandaskan peraturan perundangundangan dan nilai-nilai etika. ${ }^{29}$

Menurut Keputusan Menteri Badan Usaha Milik Negara No. KEP-117/MMBU/2002 tentang Penerapan Praktek Good Corporate Governance pada Badan Usaha Milik Negara $(B U M N)$, istilah corporate governance adalah suatu proses dan struktur yang digunakan oleh organ BUMN untuk meningkatkan keberhasilan usaha dan akuntabilitas perusahaan, guna mewujudkan nilai pemegang saham dalam jangka panjang, dengan tetap memperhatikan kepentingan stakeholder lainnya berdasarkan peraturan perundangan dan nilai-nilai etika.

Menurut Bismar Nasution, prinsip-prinsip good corporate governance terdapat dalam Undang-Undang No. 19 Tahun 2003 tentang Badan Usaha Milik Negara (UU BUMN). Pada Pasal 36 ayat (1) UU BUMN, menyatakan bahwa perum dalam menyelenggarakan usahanya harus berdasarkan pada prinsip pengelolaan perusahaan yang sehat. Ketentuan ini juga diatur dalam Pasal 5 ayat (3) Jo. Pasal 6 ayat (3) UU BUMN yang mewajibkan direksi, komisaris, dan dewan pengawas dalam melaksanakan tugasnya harus melaksanakan prinsip-prinsip profesionalisme, efisiensi, transparansi, kemandirian, akuntabilitas, pertanggungjawaban, serta kewajaran. ${ }^{30}$

Bagi BUMN implementasi prinsip-prinsip corporate governance diatur dalam Keputusan Menteri Negara BUMN No. KEP.117/M-MBU/2002 dengan prinsip-prinsip sebagai berikut:

a. "Transparansi, yaitu keterbukaan dalam melaksanakan proses pengambilan keputusan dan keterbukaan dalam mengemukakan informasi materiil dan relevan mengenai perusahaan.

b. Kemandirian, yaitu keadaan dimana perusahaan dikelola secara professional tanpa benturan kepentingan dan pengaruh/tekanan dari pihak manapun yang

${ }_{27}$ Sukrisno Agoes, Etika Bisnis dan Profesi, (Jakarta: Salemba Empat, 2011).

${ }_{28}$ A. Dwi Kusumastuti, Pengaruh Good Corporate Governance Terhadap Kinerja Perusahaan Pada Perusahaan-Perusahaan Manufaktur Yang Terdaftar di Bursa Efek Indonesia Tahun 2011, (Surakarta: Universitas Surakarta, 2013).

29 Adrian Sutedi, Good Corporate Governance, (Jakarta: Sinar Grafika, 2011).

3o Bismar Nasution, "Menuju Sistem Pengelolaan BUMN Yang Efektif dan Efisien", https://bismarnasution.com/menuju-sistem-pengelolaan-bumn-yang-efektif-dan-efisien/., diakses pada hari Minggu, tanggal 24 Mei 2020. 
Vol. 2 No. 2 Juli 2020

tidak sesuai dengan peraturan perundang-undangan yang berlaku dan prinsipprinsip korporasi yang sehat.

c. akuntabilitas, yaitu kejelasan fungsi, pelaksanaan dan pertanggungjawaban organ sehingga pengelolaan perusahaan terlaksana secara efektif;

d. pertanggungjawaban, kesesuaian di dalam pengelolaan perusahaan terhadap peraturan perundang-undangan yang berlaku dan prinsip-prinsip korporasi yang sehat;

e. kewajaran, yaitu keadilan dan kesetaraan di dalam memenuhi hak-hak stakeholders yang timbul berdasarkan perjanjian dan peraturan perundangundangan yang berlaku.

Kaitan teori stakeholder dengan penelitian ini bahwasanya dalam penerapan good corporate governance (GCG) di PTPN IV bukanlah semata-mata untuk kepentingan pemilik perusahaan (dhi. Negara), akan tetapi untuk kepentingan umum, yaitu seluruh pemangku kepentingan, terutama masyarakat sekitar kebun-kebun kelapa sawit milik PTPN IV tersebut.

\section{Legal System Theory (Teori Sistem Hukum)}

Teori sistem hukum yang dikemukakan oleh Lawrence M. Friedman yang menyatakan efektif dan berhasil tidaknya penegakan hukum tergantung dari 3 (tiga) unsur sistem hukum, yaitu ${ }^{31}$ :

a. "Substansi Hukum (Substance of The Law)

Substansi hukum menurut Lawrence M. Friedman, menyatakan bahwa : "Anoher aspect of the legal system is its substance. By this is meant the actual rules, norm, and behavioral patterns of people inside the system ...the stress here is on living law, not just rules in law books". ${ }^{32}$ Aspek lain dari sistem hukum adalah substansinya. Adapun yang dimaksud dengan substansinya adalah aturan, norma, dan pola perilaku nyata manusia yang berada dalam sistem itu. Jadi, substansi hukum menyangkut peraturan perundang-undangan yang berlaku yang memiliki kekuatan yang mengikat dan menjadi pedoman bagi aparat penegak hukum.

b. Struktur Hukum (Structure of The Law)

Mengenai struktur hukum, Lawrence M. Friedman menjelaskan ${ }^{33}$ : "To begin with, the legal system has the structure of a legal system consists of elements of this kind: the number and size of courts; their jurisdiction... Structure also means how the legislature is organized ...what procedures the police department follow, and so on. Structure, in way, is a kind of cross section of the legal system... a kind of still photograph, with freezes the action".

Struktur dari sistem hukum terdiri atas unsur berikut ini, jumlah dan ukuran pengadilan, yurisdiksinya (termasuk jenis kasus yang berwenang mereka

hlm. 6 .

${ }^{31}$ Lawrence M. Friedman, Sistem Hukum : Perspektif Ilmu Sosial, (Bandung : Nusa Media, 2013),

${ }^{32}$ Lawrence M. Friedman, Loc.cit., hlm. 5-6.

33 Lawrence M. Friedman, American Law : An Introduction, (New York : W.W. Norton \& Company, 1984), hlm. 5-6. 
Fakultas Hukum Universitas Komputer Indonesia

Vol. 2 No. 2 Juli 2020

periksa), dan tata cara naik banding dari pengadilan ke pengadilan lainnya. Struktur juga berarti bagaimana badan legislatif ditata, apa yang boleh dan tidak boleh dilakukan oleh Presiden, prosedur ada yang diikuti oleh Kepolisian dan sebagainya. Jadi, struktur (legal structure) terdiri dari lembaga hukum yang ada dimaksudkan untuk menjalankan seperangkat hukum yang ada atau yang dikenal dengan Criminal Justice System (CJS). CJS terdiri dari 4 (empat) lembaga, yaitu : Penyidik (Kepolisian), Penuntut Umum (Kejaksaan), Pengadilan (Hakim), Lembaga Pemasyarakatan (Direktorat Jenderal Pemasyarakatan Kementerian Hukum dan Hak Asasi Manusia RI), dan Advokat. Seluruh struktur hukum tersebut saling bekerja mendukung satu sama lain. ${ }^{34}$

Struktur adalah pola yang menunjukkan tentang bagaimana hukum dijalankan menurut ketentuan-ketentuan formalnya. Struktur ini menunjukkan bagaimana pengadilan, pembuat hukum dan badan serta proses hukum itu berjalan dan dijalankan. Di Indonesia misalnya jika berbicara tentang struktur sistem hukum Indonesia, maka termasuk di dalamnya struktur institusi-institusi penegakan hukum seperti Kepolisian, Kejaksaan, Lembaga Pemasyarakatan, Pengadilan, dan Advokat. ${ }^{35}$

c. Budaya Hukum (Legal Culture)

Mengenai budaya hukum, Lawrence M. Friedman, berpendapat: "The third component of legal system, of legal culture. By this we mean people's attitudes toward law and legal system their belief ...in other word, is the climinate of social thought and social force which determines how law is used, avoided, or abused". ${ }^{36}$ Kultur hukum menyangkut budaya hukum yang merupakan sikap manusia (termasuk budaya hukum aparat penegak hukumnya) terhadap hukum dan sistem hukum. Sebaik apapun penataan struktur hukum untuk menjalankan aturan hukum yang ditetapkan dan sebaik apapun kualitas substansi hukum yang dibuat tanpa didukung budaya hukum oleh orang-orang yang terlibat dalam sistem dan masyarakat, maka penegakan hukum tidak akan berjalan secara efektif.

Dengan kata lain, Lawrence M. Friedman mengemukakan bahwa efektif dan berhasil tidaknya penegakan hukum tergantung 3 (tiga) unsur sistem hukum, yakni :

34 Dikaji dari perspektif Sistem Peradilan Pidana (Criminal Justice System), maka di Indonesia dikenal 5 (lima) institusi yang merupakan sub sistem peradilan pidana. Terminologi lima institusi tersebut dikenal sebagai Panca Wangsa Penegak Hukum. Meurut Mardjono Reksodiputro, maka Sistem Peradilan Pidana merupakan sistem dalam suatu masyarakat untuk menanggulangi masalah kejahatan. Sumber : Mardjono Reksodiputro, Hak Asasi Manusia Dalam Sistem Peradilan Pidana : Kumpulan Karangan, Buku Ketiga, (Jakarta : Pusat Pelayanan Keadilan dan Pengabdian Hukum Universitas Indonesia, 1994), hlm. 84-85.

35 Achmad Ali, Keterpurukan Hukum di Indonesia : Studi Tentang Perkembangan Pemikiran Hukum di Indonesia, Cet. Ke-2, (Surakarta : Muhammadiyah University Press, 2004), hlm. 36, menyatakan bahwa : "Jika kita ingin melihat hukum secara lebih utuh, maka hendaknya hukum tidak sekedar dipandang sebagai kumpulan asas-asas dan aturan-aturan, melainkan hendaknya kita memandang hukum dalam wujudnya sebagai tatanan yang utuh, yang mencakup tatanan sosial dan tatanan politik. Sehingga dapat dikatakan bahwa pendidikan hukum gaya lama hanya mempelajari hukum sebagai tatanan politik yaitu hukum positif, hukum negara yang oleh Roberto M. Unger diistilahkan sebagai hukum birokrat. Kalangan hukum positif mengatakan bahwa di luar hukum positif (hukum negara) tidak ada lagi hukum”.

${ }^{36}$ Lawrence M. Friedman, Op.cit., hlm. 6. 
Vol. 2 No. 2 Juli 2020

struktur hukum (structure of law), substansi hukum (substance of the law), dan budaya hukum (legal culture). Struktur hukum menyangkut aparat penegak hukum, substansi hukum meliputi perangkat perundang-undangan dan budaya hukum merupakan hukum yang hidup (living law) yang dianut dalam suatu masyarakat.

Kaitannya dengan penelitian ini bahwasanya dalam penerapan good corporate governance (GCG) di bidang pengamanan aset di PTPN IV dapat diukur dengan ketiga unsur sistem hukum tersebut, yaitu: substansi hukumnya (UU Perseroan Terbatas, UU BUMN, UU Kehutanan, UU Perkebunan, dan lain sebagainya); struktur hukumnya (aparat penegak hukum: PPNS Kehutanan dan Polri); budaya hukum perusahaan. Ketiga sistem tersebut saling terkait satu sama lain. Upaya penegakan hukum secara sistemik harus memperhatikan unsur-unsur sistem hukum tersebut karena merupakan esensi dari penegakan hukum sehingga proses penegakan hukum dan keadilan secara internal perusahaan maupun eksternal dapat diwujudkan secara nyata, minimal dapat mengurangi pencurian dan penggelapan TBS kelapa sawit. Dengan berkurangnya pencurian dan penggelapan TBS kelapa sawit, otomatis dapat meningkatkan produksi perusahaan. Produksi perusahaan meningkat, maka kesejahteraan karyawan juga meningkat. Dengan didukung teori stakeholder, maka peningkatan pendapatan perusahaan diharapkan dapat meningkatkan taraf hidup masyarakat di sekitar kebun-kebun kelapa sawit milik perusahaan.

\section{HASIL PENELITIAN \& PEMBAHASAN}

Penerapan Tata Kelola Perusahaan Yang Baik (Good Corporate Governance) Dalam Bidang Pengamanan Aset Untuk Meminimalisir Pencurian Tandan Buah Segar (TBS) Kelapa Sawit di PTPN IV

Tata Kelola Perusahaan yang Baik (Good Corporate Governance), yang selanjutnya disebut GCG adalah prinsip-prinsip yang mendasari suatu proses dan mekanisme pengelolaan perusahaan berlandaskan peraturan perundang-undangan dan etika berusaha. ${ }^{37}$ Proses dan mekanisme atau tata kelola yang dimaksud adalah bagaimana sebuah perusahaan dipimpin, diarahkan dan dikendalikan (lead, direct, dan control) dan perlu dijabarkan dalam suatu bentuk pedoman yang disebut Pedoman Tata Kelola Perusahaan (Code of Corporate Governance atau Code of CG).

Pedoman Tata Kelola Perusahaan ini sebagai pedoman umum dalam pengelolaan perusahaan dan dijabarkan lebih lanjut ke dalam pedoman yang lebih rinci oleh masingmasing organ perusahaan sesuai dengan tugas dan tanggung jawabnya. Pedoman tersebut merupakan penyempurnaan (revisi) dari pedoman yang telah disusun pada tahun 2013. Materi untuk penyempurnaan Pedoman Tata Kelola Perusahaan tersebut bersumber dari: Anggaran Dasar Perusahaan; Undang-Undang No. 40 Tahun 2007 tentang Perseroan Terbatas; Undang-Undang No. 19 Tahun 2003 tentang Badan Usaha Milik Negara (BUMN), Peraturan Menteri Negara BUMN No. PER-01/MBU/2011 tertanggal 01 Agustus 2011 tentang Penerapan Tata Kelola Perusahaan Yang Baik (Good Corporate Governance) Pada Badan Usaha Milik Negara (BUMN), yang terakhir diubah dengan

37 Pasal 1 angka 1 Peraturan Menteri Negara BUMN No. PER-01/MBU/2011 tentang Penerapan Tata Kelola Perusahaan Yang Baik (Good Corporate Governance) Pada Badan Usaha Milik Negara (BUMN). 
Fakultas Hukum Universitas Komputer Indonesia

Vol. 2 No. 2 Juli 2020

Peraturan Menteri Negara BUMN No. PER-09/MBU/2012, tertanggal 06 Juli 2012 dan Peraturan Menteri Negara BUMN No. PER-12/MBU/2012, tertanggal 24 Agustus 2012 tentang Organ Pendukung Dewan Komisaris/Dewan Pengawas BUMN serta peraturan perundang-undangan yang berlaku.

Sebagaimana telah dijelaskan sebelumnya bahwasanya pelaksanaan tata kelola perusahaan didasarkan pada prinsip-prinsip GCG, yaitu: transparansi (transparency); akuntabilitas (accountability); pertanggungjawaban (responsibility); kemandirian (independency); dan kewajaran (fairness) sesuai Keputusan Bersama Dewan Komisaris dan Direksi PT. Perkebunan Nusantara IV No. DK/18/KPTS/2016 dan No. 04.03/02/KPTS/2016 tentang Pemberlakuan Infrastruktur Good Corporate Governance PT. Perkebunan Nusantara IV.

\section{Pemberlakuan Ketentuan Infrastruktur Good Corporate Governance Pada PTPN IV}

PT. Perkebunan Nusantara IV disingkat PTPN IV didirikan berdasarkan Peraturan Pemerintah RI No. 9 Tahun 1996 tentang Peleburan Perusahaan Perseroan (Persero) PT. Perkebunan VI, Perusahaan Perseroan (Persero) PT. Perkebunan VII, dan Perusahaan Perseroan (Persero) PT. Perkebunan VIII menjadi Perusahaan Perseroan (Persero) PT. Perkebunan Nusantara IV dan Akta Pendirian Perusahaan Perseroan (Persero) PT. Perkebunan Nusantara IV No. 37 tertanggal 11 Maret 1996 yang dibuat dihadapan Notaris Harun Kamil, SH; Anggaran Dasar tersebut telah mendapat pengesahan dari Menteri Kehakiman RI melalui Surat Keputusan No. C2-8332 HT.01.01.Th.96, tertanggal 08 Agustus 1996 serta diumumkan dalam Berita Negara Republik Indonesia No. 81 tertanggal 08 Oktober 1996; Tambahan Berita Negara RI No. 8675. Anggaran Dasar Perseroan telah beberapa kali mengalami perubahan terakhir berdasarkan keputusan Para Pemegang Saham No. SK-44/MBU/03/2016 dan No. KPJAK/Hold/AD.NIV/03/2016 yang dinyatakan dalam Akta No. 05 tertanggal 14 Maret 2016 yang dibuat dihadapan Notaris Nanda Fauz Iwan, SH, M.Kn., dan telah mendapat pengesahan dari Kementerian Hukum dan HAM sesuai Surat Keputusan No. AHUAH.01.03.00336415, tertanggal 01 April 2016. ${ }^{38}$

Pada awalnya PT. Perkebunan Nusantara IV adalah Badan Usaha Milik Negara (BUMN) berbentuk Perseroan Terbatas (PT) (selanjutnya disebut PTPN IV). Menurut Undang-Undang No. 19 Tahun 2003 tentang Badan Usaha Milik Negara (selanjutnya disebut UU BUMN), BUMN terbagi atas BUMN Perusahaan Umum (Perum) dan BUMN Perseroan (PT). BUMN Perum seluruh modalnya berasal dari Negara dan tidak terbagi atas saham-saham bertujuan untuk kemanfaatan umum berupa penyediaan barang dan/atau jasa yang bermutu tinggi dan sekaligus mengejar keuntungan berdasarkan prinsip pengelolaan perusahaan. Sedangkan BUMN Perseroan (PT) adalah BUMN yang berbentuk Perseroan Terbatas (PT) yang modalnya terbagi dalam saham yang seluruh

${ }_{38}^{8}$ Bab I angka 1.4. Keputusan Bersama Dewan Komisaris dan Direksi PT. Perkebunan Nusantara IV tentang Pemberlakuan Infrastruktur GCG PTPN IV. 
Fakultas Hukum Universitas Komputer Indonesia

Vol. 2 No. 2 Juli 2020

atau paling sedikit 51\% (lima puluh satu persen) sahamnya dimiliki oleh Negara Republik Indonesia yang tujuan utamanya mengejar keuntungan. ${ }^{39}$

Saat ini saham negara melalui penyertaan langsung pada PTPN IV hanya sebesar 10\% saja, tidak sampai $51 \%$ sebab PTPN IV sudah menjadi anak perusahaan dari "holding company" PT. Perkebunan Nusantara III (Persero). Dihilangkannya status dilakukan dengan mengalihkan saham milik negara pada PTPN IV kepada PTPN III sebagai induk BUMN perkebunan. Adapun dasar hukum pembentukan holding BUMN tertuang dalam Peraturan Pemerintah No. 72 Tahun 2016 tentang Perubahan Atas Peraturan Pemerintah No. 44 Tahun 2005 tentang Tata Cara Penyertaan dan Penatausahaan Modal Negara Pada Badan Usaha Milik Negara dan Perseroan Terbatas. ${ }^{40}$

\section{Penggunaan Alat Berteknologi Tinggi dan Aplikasi "Smart Security of Integrity" di Bidang Pengamanan Aset Untuk Meminimalkan Pencurian TBS Kelapa Sawit Pada Kebun-Kebun PTPN IV}

Prinsip pengamanan yang tidak boleh diabaikan adalah mengetahui asset yang menjadi obyek pengamatan dan mengetahui ancamannya, perlu dibutuhkan konsep penanganan keamanan yang efektif dan terpadu baik keamanan regular dari tokoh masyarakat lingkungan, lembaga-lembaga masyarakat maupun tingkat korwil setempat sehingga dapat berkoordinasi dengan optimal untuk terciptanya situasi dan kondisi yang aman dan nyaman tentunya sesuai dengan Tugas Pokok, Fungsi, Peranan sebagai Petugas Pengamanan (Security) Kebun milik PTPN IV.

Adapun maksud dan tujuan pengamanan terpadu dengan menggunakan alat berteknologi tinggi dan aplikasi "Smart Security of Integrity" di bidang pengamanan aset untuk meminimalkan pencurian TBS kelapa sawit pada kebun-kebun PTPN IV, antara lain:

1. Memperkecil potensi terhadap kemungkinan terjadinya ancaman, hambatan, gangguan keamanan;

2. Memberikan peningkatan keamanan, ketertiban, dan kenyamanan di Kawasan Perkebunan, sehingga dapat memberikan pelayanan yang maksimal.

\section{a. Perlengkapan dan Peralatan Kerja Yang Dibutuhkan}

Pelaksana pekerjaan menyediakan perlengkapan dan peralatan kerja yang dibutuh sebagai berikut :

a. Pelaksana Pekerjaan menyediakan pakaian \& sarana kerja diperlukan untuk mendukung pekerjaan keamanan sesuai standar perlengkapan tenaga pengamanan berdasarkan ketentuan yang berlaku.

b. Pelaksana Pekerjaan berkewajiban menyediakan pakaian \& sarana kerja yang diberikan pada bulan pertama pelaksanaan kontrak yang ditagihkan setelah penyerahan kepada pekerja dengan rincian sebagai berikut:

39 Lihat: Pasal 1 angka 2 UU BUMN.

40 Adapun dasar hukum pembentukan holding BUMN tertuang dalam Peraturan Pemerintah No. 72 Tahun 2016 tentang Perubahan Atas Peraturan Pemerintah No. 44 Tahun 2005 tentang Tata Cara Penyertaan dan Penatausahaan Modal Negara Pada Badan Usaha Milik Negara dan Perseroan Terbatas. 
Vol. 2 No. 2 Juli 2020

Adapun sarana dan prasarana penunjang kinerja keamanan dapat dilihat pada Tabel 1 di bawah ini:

Tabel 1

Sarana dan Prasarana Penunjang Kinerja Keamanan

\begin{tabular}{|lc|}
\hline \multicolumn{1}{|c}{ Sarana Kerja } & Jumlah \\
1. Pakaian Dinas Lapangan PDL untuk 528 Personil & 2 Set/Tahun \\
2. Jaket Lapangan sebanyak untuk 528 Personil & 1 Set/Tahun \\
$\begin{array}{l}\text { 3. Topi, Sepatu, Kaos Kaki, Peluit, Tali Peluit, Sabuk, Kopel Rem, } \\
\text { dan Sarungnya, Tongkat Polri dan Sarungnya, Jas Hujan }\end{array}$ & 1 Set/Tahun \\
$\begin{array}{l}\text { Standar untuk semua anggota untuk 528 Personil } \\
\text { 4. Senter Patroli }\end{array}$ & 283 Set/tahun \\
\hline
\end{tabular}

Sumber : Data Primer dari PTPN IV, Maret 2020.

\section{b. Pola Kerja Pengamanan}

Adapun pola kerja pengamanan pada PTPN IV untuk meminimalisir pencurian aset kebun, terdiri dari: Pengamanan Tertutup dan Pengamanan Terbuka. Pola pengamanan tertutup (Pam Tertutup) merupakan operasi intelijen sebagai bagian dari kegiatan pre-emtif untuk melakukan pemetaan, penggalangan, dan penggembosan terhadap para pelaku kejahatan yang berpotensi merugikan PTPN IV. Kegiatan intelijen dilakukan paling awal dan berkesinambungan guna membangun jaringan informasi dan pengamanan terluar sebelum para pelaku kejahatan bertindak, maka petugas keamanan akan mendapatkan informasi mengenai hal tersebut dan berkoordinasi dengan pihak pengamanan terbuka. ${ }^{41}$

Adapun cara kerja Pam Tertutup ini, yaitu: ${ }^{42}$ a. Infiltrasi jaringan; b. Penggalangan; c. Penggembosan; dan d. Perang urat syaraf/media.

Pengamanan Terbuka (Pam Terbuka) dilakukan pada masing-masing kebun. Pengawasan dilakukan oleh Tim Pengamanan selama 24 jam secara terus-menerus dengan pembagian kelompok kerja dan waktu atau shift jaga masing-masing menjadi 3 (tiga) kelompok dan 2 (dua) shift. Masing-masing shift dengan menyesuaikan jumlah anggota dipimpin oleh Manager Unit Pengamanan, untuk pola kerja 4:2, yaitu: 2 (dua) hari siang, 2 (dua) hari malam, dan 2 (dua) hari libur, atau menyesuaikan kebutuhan lapangan. ${ }^{43}$

Adapun jam kerja berdasarkan shift tersebut, yaitu: ${ }^{44}$
a. Shift I
: $\quad 07.00 \mathrm{Wib}$ s.d. $19.00 \mathrm{Wib}$
b. Shift II
: $\quad 19.00 \mathrm{Wib}$ s.d. $07.00 \mathrm{Wib}$
c. Shift III
: Off/Libur

${ }^{41}$ Wawancara dengan Roy Markori Purba, Kasubbag Keamanan PTPN IV pada hari Kamis, tanggal 26 Maret 2020 di Kantor Pusat PTPN IV, Medan.

${ }_{42} \mathrm{Ibid}$.

43 Ibid.

44 Ibid. 
Fakultas Hukum Universitas Komputer Indonesia

Vol. 2 No. 2 Juli 2020

d. Jam Kerja : Pola kerja $8-12$ jam menyesuaikan dengan kondisi lapangan. berikut: $^{45}$

Penempatan pos terdapat 4 (empat) jenis penjagaan dengan rincian, sebagai

a. Pos Stasioner / penjagaan akses keluar masuk kebun;

b. Pos Bergerak / penjagaan daerah rawan afdeling;

c. Patroli Area / penjagaan daerah rawan blok;

d. Patroli Pengawasan Kebun / manajemen pengawasan mutu.

Adapun metode penjagaan kebun PTPN IV oleh tenaga satuan pengamanan terpadu sewaktu serah terima tugas / pergantian shift, sebagai berikut: ${ }^{46}$

a. Minimal 15 S/d 30 menit sebelum Serah Terima Tugas antar Shift dilaksanakan, Petugas Shift yang baru naik tugas sudah mempersiapkan diri.

b. Petugas melakukan Apel di dekat Pos, dilakukan Absensi, Pemeriksaan teliti mengenai Perlengkapan dan Seragam serta Kerapihan Kebersihan Baju, dan lainlain.

c. Petugas melaksanakan serah terima tugas jaga di plotingan masing masing di antar oleh sarana transportasi.

Adapun hal-hal yang perlu diperhatikan pada saat serah terima jaga, antara lain: ${ }^{47}$

a. Pos Stasioner / Penjagaan Akses Keluar Masuk Kebun

1) Chek perlengkapan alat kelengkapan kerja

2) Chek surat jalan kendaraan keluar masuk

3) Chek buku mutasi / catatan harian \& Chek buku tamu

4) Petugas jaga lama melaporkan kegiatan selama tugas jaga kepada petugas jaga baru (info, perintah, kegiatan, temuan dan masalah)

b. Pos Bergerak / Penjagaan Daerah Rawan Affdeling

1) Patroli area Perkebunan PT. Perkebunan Nusantara IV, Sumatera Utara

2) Hasil patroli area (situasi dan kondisi selama tugas jaga)

3) Temuan hasil patroli

4) Serah terima buku patroli dan alkap Traffic (pengaturan kendaraan traffic)

5) Petugas jaga lama melaporkan tugas jaga 1 x 12 jam kepada petugas jaga baru

6) Situasi dan kondisi area depan dan traffic

7) Serah terima alkap (alat kelengkapan kerja traffic)

8) Melaporkan temuan atau kejadian di traffic selama tugas jaga 1x 12 jam

c. Patroli Area / Penjagaan Daerah Rawan Blok

1) Hasil patroli area (situasi dan kondisi selama tugas jaga)

2) Temuan hasil patroli

3) Serah terima buku patroli dan alkap \& Traffic (pengaturan kendaraan traffic)

4) Petugas jaga lama melaporkan tugas jaga 1 x 12 jam kepada petugas jaga baru

$$
{ }^{45} \text { Ibid. } \text { Ibid. }
$$

47 Ibid. 
Vol. 2 No. 2 Juli 2020

5) Situasi dan kondisi area depan dan traffic

6) Serah terima alkap (alat kelengkapan kerja traffic)

7) Melaporkan temuan atau kejadian di traffic selama tugas jaga $1 \mathrm{x} 12$ jam.

\section{c. Pengamanan Terpadu dan Terintegrasi}

Sistem keamanan terpadu terdiri dari berbagai metode dan konsep pengamanan yang tidak hanya menggunakan "hard skill" tetapi juga menggunakan "soft skill" di bantu dengan penggunaan teknologi keamanan yang modern dilandasi dengan kearifan lokal yang terukur.

Adapun metode pelaksanaannya, yaitu:

a. Daya Tangkal, mampu memberikan rasa gentar dan segan bagi pelaku kejahatan untuk melakukan tindak kejahatan dengan melakukan pengamanan tertutup.

b. Daya Deteksi, mampu mendeteksi gerakan persiapan dan perencanaan pelaku kejahatan sebelum menjalankan kegiatannya.

c. Daya Hambat, mampu menghambat pergerakan masuknya pelaku kejahatan ke dalam kebun.

d. Daya Respon, mampu merespon pelaku tindak kejahatan ketika melakukan kegiatan kejahatan.

e. Daya Tolak, mampu menolak/menghilangkan tindak kejahatan di area kebun.

Lapisan pengamanan, terdiri dari: Ring/Zona 1 (terlarang); Ring/Zona 2 (terbatas); dan Ring/Zona 3 (bebas). Adapun yang termasuk ke dalam ring-ring atau zonazona sebagai lapisan pengamanan, yaitu: Ring/Zona 1 yaitu penggunaan peralatan keamanan untuk menunjang pengamanan. Satuan pengaman sebagai lapisan pengamanan terakhir yang mengamankan objek pengamanan yaitu TBS. Ring/Zona 2 berupa paritan dan pagar sebagai lapisan keamanan sesuai dengan kaidah-kaidah "Crime Prevention Through Environment Design" (CPTED) ${ }^{48}$ Ring/Zona 3 berupa rumah warga sekitar yang terbukti oknum-oknum masyarakat melakukan tindakan memanen secara tidak sah di lingkungan perkebunan milik PTPN IV.

CPTED konsep dikemukakan oleh C. Ray Jeffery, bahwa: "the proper design and effective use of the built environment can lead to a reduction in the fear of crime and the incidence of crime, and to an improvement in the quality of life". ${ }^{49}$ Terjemahan: "desain yang tepat dan penggunaan lingkungan binaan yang efektif dapat mengarah pada berkurangnya rasa takut akan kejahatan dan timbulnya kejahatan, dan peningkatan kualitas hidup".

Adapun dimensi pengamanan, terdiri dari: pembuat keputusan; karyawan; masyarakat sekitar; penjaga keamanan; dan pihak berwajib.

Pengertian Intelijen secara umum : asal kata dari kata "inteligencia" artinya kecerdasan yang disinonimkan dengan kepandaian, brilian, bersinar (intelektual), serba

48 “Crime Prevention Through Environment Design" (CPTED) merupakan konsep yang mendasari pembangunan wilayah yang berorientasi berkelanjutan, terus-menerus, dalam mencegah terjadinya kejahatan dan kecelakaan secara dini, wujudnya antara lain memasang lampu penerangan jalan secara swadaya di depan rumah-rumah masyarakat, khususnya yang belum terjangkau pembangunan penerangan jalan umum. Lihat: Timothy D. Crowe, Crime Prevention Through Environmental Design: Applications of Architectural Design and Space Management Concepts, ${ }^{\text {nd }}$ Edition, (Boston, USA: Butterworth-Heinemann, 20oo), hlm. 1. 49 Ibid., hlm. 1. 
Vol. 2 No. 2 Juli 2020

tahu, berakal dan flexibel. Personil yang bertugas di intelijen harus memiliki standrad tingkat kecerdasan dan pelatihan di atas rata-rata, sehingga mampu mengetahui banyak informasi tapi rendah hati, tidak sombong, mudah bergaul/luwes, pandai membawa diri dan mudah bekerja sama.

Pengamanan Tertutup adalah segala usaha, pekerjaan, kegiatan yang dilakukan secara terencana dan terarah untuk mencegah, dan menangkal serta menemukan jejak, menggagalkan usaha-usaha, pekerjaan dan kegiatan pihak lain/oposisi dalam melakukan sabotase, spionase/pencurian bahan keterangan dan penggalangan yang dapat mengancam pelaksanaan kegiatan perusahaan.

Penyelidikan terbuka adalah penelitian (riset) dan wawancara (interview). Sedangkan penyelidikan tertutup, berupa: "ellicting" (elitasi); penjajakan (pengintaian); penyusupan; penyadapan; dan penyamaran.

Adapun hakikat pengamanan tertutup adalah untuk tetap terpeliharanya situasi keamanan yang kondusif dimana tidak ada kesempatan atau peluang bagi pihak lain/pelaku kejahatan untuk melaksanakan tindak kejahatan. Tujuan pengamanan adalah untuk terhindarnya usaha-usaha, pekerjaan, dan kegiatan pihak pelaku kejahatan untuk melakukan sabotase, spionase/pengumpulan bahan keterangan dan penggalangan yang dapat mengganggu keamanan, keselamatan dan ketentraman atau merugikan pihak kebun. Prinsip pengamanan, terdiri dari:

a. Prinsip preventif (pencegahan), kegiatan pengamanan intelijen lebih mengutamakan pencegahan daripada melakukan penindakan/penegakan hukum.

b. Prinsip memegang teguh tujuan, segala kegiatan yang dilakukan harus selalu diorientasikan kepada tujuan yang hendak dicapai atau diwujudkan.

c. Prinsip tidak mengambil risiko, kegiatan yang dilakukan harus berdasarkan perencanaan yang baik berlandaskan pada hasil penyelidikan yang akurat, sehingga kemungkinan resiko yang dihadapi sudah diperhitungkan secara matang dan dinilai sebagai kemungkinan resiko yang terkecil.

d. Prinsip modifikasi, dengan modifikasi metode, taktik, dan teknik, maka usaha pengamanan intelijen yang dilakukan tidak berpola atau tidak monoton sehingga sulit dikenali oleh pihak lawan atau pihak lain yang akan menggunakan/mengancam sistem pengamanan yang dilakukan.

e. Prinsip kewaspadaan, petugas pelaksana pengamanan harus memiliki sikap kewaspadaan tinggi dalam melaksanakan tugasnya sehingga tidak akan dihadapkan kepada pendadakan-pendadakan yang dilancarkan pihak lain.

f. Prinsip tidak mengganggu kebebasan bergerak, petugas pelaksana pengamanan dimungkinkan untuk dapat secara leluasa bergerak di daerah lokasi pengamanannya

g. Prinsip kerjasama, dalam menjalankan tugas, petugas-petugas pengamanan harus melakukan kerjasama dengan segenap aparat pengamanan yang ada di daerah lokasi pengamanan.

Adapun sasaran pengamanan dilakukan terhadap: orang, benda, kegiatan, bahan keterangan, dan tempat lokasi. Bentuk pengamanan intelijen, yaitu: 
Vol. 2 No. 2 Juli 2020

a. Pengamanan langsung, merupakan kegiatan pengamanan yang secara fisik dilakukan oleh personil intelijen terhadap objek atau sasaran pengamanan.

b. Pengamanan tidak langsung, suatu awal kegiatan yang dilaksanakan dengan melakukan pengecekan, pengawasan, dan pemeriksaan secara administratif terhadpa penerbitan surat izin melintas, perizinan, dan rekomendasi pelaksanaan pekerjaan.

Adapun rencana dan program pelaksanaan dari tindakan pidana pencurian dan penggelapan di area milik PTPN IV dapat dilakukan dengan penyidikan intern dan ekstern. Pengamanan internal dilakukan untuk mengetahui apakah itndakan pencurian tersebut dilakukan dan/atau ada kaitannya dengna internal perusahaan, yaitu: BKO, TNI, Polri, PAPAM, Security, Centeng, Staff, dan Outsourcing yang bekerja di area kebun PTPN IV. Sedangkan pengamanan eksternal adalah pengamanan yang dilakukan dan/atau ada kaitannya dengan eksternal perusahaan, yaitu: Pengusaha, Ninja Sawit, Pengepul, dan Oknum Penguasa lainnya, baik yang berada di area maupun di luar area perkebunan milik PTPN IV.

Adapun program pelaksanaan pengamanan dari tindakan pencurian di kebunkebun PTPN IV, terdiri dari:

a. Manajemen Risiko ("Risk Management"), yaitu:

1) Asesmen Risiko (“Risk Assessment”), terdiri dari:

a) Identifikasi : menghasilkan daftar risiko yang berpotensi mengganggu pengamanan;

b) Analisis : menilai kemungkinan dan dampak dari setiap risiko yang diidentifikasi, dan tingkat risiko dari kemungkinan alternatif;

c) Prioritas : memprioritaskan daftar berdasarkan dampak.

2) Kontrol Risiko ("Risk Control"), terdiri dari:

a) Perencanaan : menghasilkan rencana pengamanan untuk menangani setiap risiko harus memastikan secara konsisten rencana manajemen risiko dengan rencana keseluruhan pengamanan;

b) Resolusi : mengidentifikasi dan mendokumentasikan tindakan pencegahan untuk tindakan "ancaman" dan peningkatan untuk "peluang";

c) Monitoring : upaya yang dilakukan secara rutin untuk mengidentifikasi pelaksanaan dari berbagai komponen program sebagaimana telah direncanakan, waktu pelaksanaan program sebagaimana telah dijadwalkan, dan kemajuan dalam mencapai tujuan program. ${ }^{50}$

b. Green, Ambre, dan Red (GAR), terdiri dari: ${ }^{51}$

${ }^{5}$ Seri Monograf 3, UNESCO Regional Office for Education in Asia and the Pacific.

${ }^{51}$ GAR Modul digunakan untuk menghitung tingkat risiko total untuk setiap bahaya yang diidentifikasi di bawah ini, tetapkan kode risiko o (Untuk Tidak Ada Risiko) hingga 10 (Untuk Risiko Maksimum) untuk masing-masing dari enam elemen. Ini adalah taksiran risiko pribadi Anda. Tambahkan skor risiko untuk menghasilkan Skor Risiko Total untuk setiap bahaya. Lihat: Anonymous, "Risk Calculation Worksheet - Calculating Risk Using GAR Model (Green-Ambre-Red)", https://www.dco.uscg.mil/Portals/9/DCO\%20Documents/National\%20Strike\%2oForce/foscr/ASTFOSCRSem inar/Presentations/Safety/ORM-GAR.pdf?ver=2017-09-14-144539-427., diakses pada hari Jumat, tanggal 27 Maret 2020 
Fakultas Hukum Universitas Komputer Indonesia

Vol. 2 No. 2 Juli 2020

1) Perencanaan (Planning), perencanaan dan persiapan harus mempertimbangkan berapa banyak informasi yang dimiliki, seberapa jelas, dan berapa banyak waktu yang dimiliki untuk merencanakan evolusi atau mengevaluasi situasi.

2) Kompleksitas acara (Event Complexity), Kompleksitas Peristiwa / Evolusi harus mempertimbangkan waktu dan situasi yang diperlukan. Secara umum, semakin lama seseorang terpapar bahaya, semakin besar risikonya. Namun, setiap keadaan unik. Misalnya, lebih banyak iterasi evolusi dapat meningkatkan peluang terjadinya kerugian tetapi mungkin memiliki efek positif meningkatkan kemahiran tim, sehingga mungkin mengurangi kemungkinan kesalahan. Ini akan tergantung pada tingkat pengalaman tim. Situasi termasuk mempertimbangkan berapa lama kondisi lingkungan akan tetap stabil dan kompleksitas pekerjaan. Tetapkan kode risiko 0 (tanpa risiko) hingga 10 (untuk risiko maksimum) untuk masing-masing dari enam kategori.

3) Supervisi (Supervision), kontrol pengawasan mempertimbangkan seberapa berkualitas penyelia itu dan apakah pengawasan yang efektif terjadi. Bahkan jika seseorang memenuhi syarat untuk melakukan tugas, pengawasan bertindak sebagai kontrol untuk meminimalkan risiko. Ini mungkin seseorang yang memeriksa apa yang sedang dilakukan untuk memastikan itu dilakukan dengan benar. Semakin tinggi risikonya, semakin banyak supervisor perlu fokus untuk mengamati dan memeriksa. Seorang pengawas yang secara aktif terlibat dalam suatu tugas (melakukan sesuatu) dengan mudah terganggu dan tidak boleh dianggap sebagai pengamat keselamatan yang efektif dalam kondisi risiko sedang hingga tinggi.

4) Lingkungan (Environment), lingkungan harus mempertimbangkan faktorfaktor yang memengaruhi kinerja personel, serta kinerja aset atau sumber daya. Ini termasuk, tetapi tidak terbatas pada, waktu, suhu, kelembaban, curah hujan, kondisi angin dan laut, kedekatan bahaya udara / navigasi dan paparan lainnya (misalnya, kekurangan oksigen, bahan kimia beracun, dan / atau cedera akibat jatuh dan tajam. benda). Lingkungan juga mencakup kesesuaian kapal untuk tugas dan peralatan yang dibutuhkan untuk tugas tersebut.

5) Seleksi petugas (Team Selection), Pemilihan tim harus mempertimbangkan kualifikasi dan tingkat pengalaman individu yang digunakan untuk peristiwa / evolusi tertentu. Individu mungkin perlu diganti selama genap / evolusi, dan tingkat pengalaman anggota tim baru harus dinilai.

6) Kebugaran petugas (Crew Fitness), kebugaran kru harus mempertimbangkan keadaan fisik dan mental kru. Ini adalah fungsi dari jumlah dan kualitas istirahat yang dimiliki anggota kru. Kualitas istirahat harus mempertimbangkan bagaimana kapal mengendarai, kelayakhunanya, potensi panjang tidur, dan gangguan apa pun. Kelelahan biasanya menjadi faktor 
Vol. 2 No. 2 Juli 2020

setelah 18 jam tanpa istirahat; Namun, kurangnya kualitas tidur menyebabkan defisit yang memperburuk efek kelelahan.

c. Proses penegakan hukum ("Police Guidance"), dengan melakukan pelaporan kepada pihak yang berwajib agar dilakukan upaya represif berupa penangkapan dan penahanan terhadap pelaku kejahatan pencurian.

Prinsip pengamanan yang tidak boleh diabaikan adalah mengetahui asset yang menjadi obyek pengamatan dan mengetahui ancamannya, perlu dibutuhkan konsep penanganan keamanan yang efektif dan terpadu baik security regular dari tokoh masyarakat lingkungan, lembaga-lembaga masyarakat maupun tingkat korwil setempat sehingga dapat berkoordinasi dengan optimal untuk terciptanya situasi dan kondisi yang aman dan nyaman. Perlengkapan dan peralatan yang dibutuhkan untuk kegiatan pengamanan sesuai dengan tugas pokok dan fungsi, dan sesuai peranan sebagai petugas pengamanan (Security) di area perkebun milik PTPN IV.

Adapun maksud dan tujuan pengamanan, yaitu: Pertama, memperkecil potensi terhadap kemungkinan terjadinya ancaman, hambatan, gangguan keamanan dari pencurian TBS di area PTPN IV, sehingga dapat dicegah secara preventif, dan dapat ditangkal sedini mungkin. Kedua, memberikan peningkatan keamanan, ketertiban dan kenyamanan di area PTPN IV, sehingga dapat memberikan pelayanan yang maksimal.

Dalam menunjang profesionalitas keamanan maka diperlukan pola kerja yang proposional, yang meliputi kegiatan-kegiatan sebagai berikut:

a. Pengamanan Tertutup, yaitu: operasi intelijen sebagai bagian dari kegiatan prepemtif untuk melakukan pemetaan, penggalangan dan pengembosan terhadap para pelaku kejahatan yang berpotensi merugikan PTPN IV.

b. Pengamanan Terbuka, PAM terbuka ini dilakukan selama 24 jam secara terusmenerus dengan pembagian kelompok kerja dan waktu atau shift jaga masingmasing menjadi tiga kelompok dan 2 (dua) shift, masing masing shift dengan menyesuaikan jumlah anggota dan dipimpin oleh Manager Unit PAM.

Demi terlaksananya kegiatan pengamanan di area PTPN IV diperlukan sistem teknologi keamanan yang modern dan tepat guna dimana sistem teknologi pengamanan di PTPN IV khususnya pengamanan Tandang Buah Segar (TBS) Kelapa Sawit.

Hambatan dan Upaya Dalam Penerapan Good Corporate Governance (GCG) di Bidang Pengamanan Aset Untuk Meminimalkan Pencurian TBS Kelapa Sawit Pada Kebun-Kebun PTPN IV

1. Hambatan Penerapan GCG di Bidang Pengamanan Aset Pada PTPN IV Ditinjau Dari Sistem Hukum

Proses terjadinya pencurian dan penggelapan TBS kelapa sawit milik PTPN IV didukung oleh pemilik modal, pengepul, dan pemilik Pabrik Kelapa Sawit (PKS) yang berada di sekitar kebun perusahaan. Adapun proses tersebut, dapat dilihat pada gambar di bawah ini:

\section{Gambar 1}

Ilustrasi Modus Pencurian dan Penggelapan TBS Kelapa Sawit Pada Kebun-Kebun PTPN IV 
Vol. 2 No. 2 Juli 2020

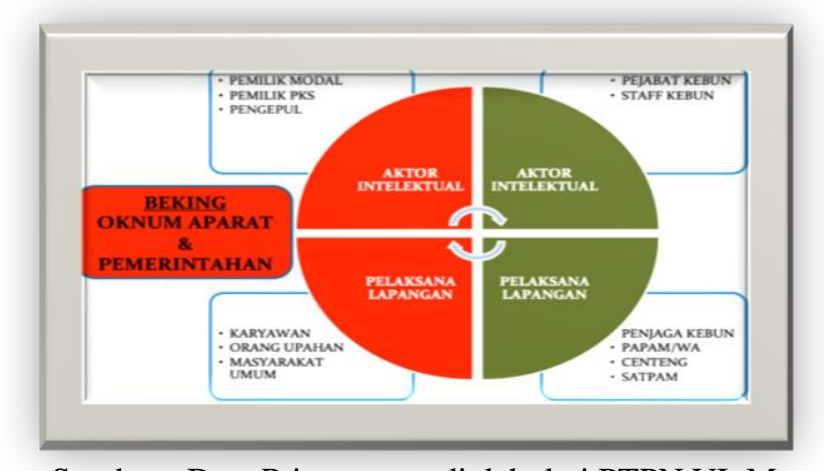

Sumber : Data Primer yang diolah dari PTPN VI, Maret 2020.

\section{Gambar 2}

Ilustrasi Modus Pencurian dan Penggelapan TBS Kelapa Sawit Pada Kebun-Kebun PTPN

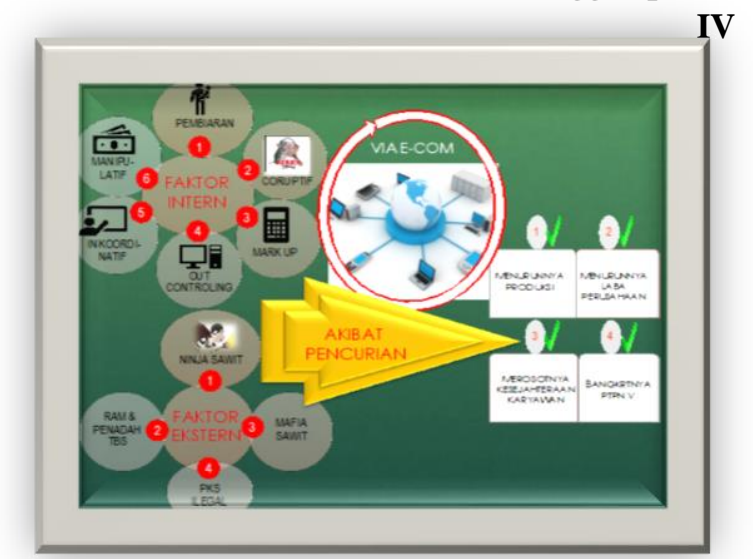

Sumber : Data Primer yang diolah dari PTPN VI, Maret 2020.

Dalam menerapkan Good Corporate Governance (GCG) di bidang pengamanan aset untuk meminimalkan pencurian TBS kelapa sawit pada kebun-kebun PTPN IV, maka petugas pengamanan menemukan hambatan-hambatan di lapangan. Adapun hambatan-hambatan tersebut berdasarkan teori sistem hukum yang digunakan dalam penelitian ini, terdiri dari: hambatan substansi hukum; hambatan struktur hukum; dan hambatan budaya hukum.

\section{a. Hambatan Substansi Hukum}

Peraturan Mahkamah Agung No. 02 Tahun 2012 tentang Penyesuaian Batasan Tindak Pidana Ringan dan Jumlah Denda Dalam KUHP merupakan pengaturan tentang spesifikasi perkara pencurian. Apabila nilai barang yang dicuri tidak lebih dari Rp. 2.500.000,- (dua juta lima ratus ribu rupiah) dan bukan pengulangan, maka terhadap pelaku akan dilakukan proses cepat dan terhadap pelaku tidak dilakukan upaya paksa berupa penahanan. ${ }^{52}$

Ketentuan Peraturan Mahkamah Agung No. 02 Tahun 2012, seyogyanya tidak berlaku terhadap pencurian hasil perkebunan karena terdapat asas lex specialis yang mengatur tindak pidana pencurian hasil perkebunan yaitu UU Perkebunan. Sementara itu,

$5^{2}$ Muhammad Soma Karya Madari, "Penyesuaian Batasan Tindak Pidana Rirngan dan Jumlah Denda Dalam KUHP Terhadap Perkara Tindak Pidana Pencurian (Analisis Peraturan Mahkamah Agung No. o2 Tahun 2012 tentang Penyesuaian Batasan Tindak Pidana Ringan dan Jumlah Denda Dalam KUHP”, Fakultas Hukum UIKA Bogor. 
Fakultas Hukum Universitas Komputer Indonesia

Vol. 2 No. 2 Juli 2020

Perma No. 02/2012 hanya diberlakukan terhadap ketentuan pidana di dalam KUH.Pidana. Setiap penegakan hukum pencurian TBS kelapa sawit pada kebun-kebun PTPN IV yang menggunakan UU Perkebunan tidak dapat menerapkan Perma No. 02/2012. Namun, ternyata di lapangan aparat penegak hukum dalam hal ini kepolisian sering menggunakan Pasal 362 dan Pasal 364 KUH.Pidana. Penggunaan ketentuan pidana dalam KUH.Pidana tentunya dapat memberlakukan juga Perma No. 02/2012, dimana pelaku tidak dilakukan upaya paksa berupa penahanan. Hal ini menjadi kendala dalam penegakan hukum tindak pidana pencurian di areal perkebunan PTPN IV.

\section{b. Hambatan Struktur Hukum}

Hambatan struktur hukum dalam menjaga aset berupa TBS kelapa sawit pada kebun-kebun PTPN IV menjadi hal yang mendasar. Sebagaimana hasil penyelidikan dari Baintelkam Mabes Polri yang didasarkan pada Laporan Intelijen No. R/LI01/XI/2017/Dit.Sosbud, tertanggal 19 November 2017 perihal Maraknya Pencurian Kelapa Sawit di Area Kerja PT. Perkebunan Nusantara IV, Sumatera Utara Yang Dilakukan oleh Oknum Masyarakat Maupun Oknum Staff dan Karyawan Secara Terorganisir dan Berkelanjutan, maka pelaku pencurian ternyata diduga adalah oknumoknum staff dan karyawan PTPN IV itu sendiri. Bahkan, pelakunya diduga oknumoknum petugas keamanan, seperti: satuan pengamanan; oknum BKO, dan oknum TNI/Polri. berikut: ${ }^{53}$

Adapun penyebab timbulnya pencurian dari pihak internal, disebabkan sebagai

1) “Adanya ketidakpuasan pelaku terhadap perusahaan, dimana pelaku telah bekerja selama belasan tahun di perusahaan tersebut. Namun, perusahaan tidak sedikitpun memberikan penghargaan terhadap kepadanya pelaku. Sehingga timbullah rasa ketidakpuasaan atau kekecewaan pelaku terhadap perusahaan yang mengakibatkan terdorongnya niat pelaku untuk melakukan tindakan pencurian terhadap aset PTPN IV.

2) Alasan klasik kurangnya perhatian perusahaan terhadap kesejahteraan si pelaku sehingga menimbulkan niat pelaku untuk mencuri aset perusahaan.

3) Areal perkebunan yang dekat dengan perkampungan masyarakat, sehingga masyarakat bisa dengan leluasa masuk ke dalam areal perkebunan. Dan disekitar perkampungan banyak terdapat tengkulak atau pengepul buah sawit yang mendorong para pelaku dengan mudah dapat menjual hasil curiannya.

4) Kurangnya personil keamanan kebun, hal ini menimbulkan keleluasaan pelaku untuk melakukan tindakan pencurian.

5) Tidak adanya laporan harian dan berkala tentang situasi pengamanan.

6) Kurang koordinasinya pengaman PTPN IV dengan Polda/Pangdam/Polres/ Kodim/Polsek/Koramil sehingga tidak efektifnya tenaga BKO pengamanan dari TNI/Polri yang ditempatkan di area perkebunan dikarenakan tidak adanya evaluasi terhadap kinerja mereka yang menimbulkan efek bola salju.

53 Wawancara dengan Roy Markori Purba, Kasubbag Keamanan PTPN IV pada hari Sabtu, tanggal 28 Maret 2020 di Kantor Pusat PTPN IV, Medan. 
Fakultas Hukum Universitas Komputer Indonesia

Vol. 2 No. 2 Juli 2020

7) Pengamanan hanya fokus ke dalam lingkungan kebun bersifat refresif, tidak melakukan operasi territorial maupun penggalangan.

8) Tidak adanya evaluasi dan review pengamanan terhadap kinerja anggota pengamanan secara berkala

9) Sistem droping gaji bulanan mereka yang sering terlambat diterima oleh mereka bahkan sampai +3 (tiga) bulan.

10) Tidak adanya alat bantu pengamanan yang modern".

Adapun langkah-langkah antisipatif dalam menjaga kemanan di areal kebun milik PTPN IV, yiatu dengan mebuat ops center dan bekerjasama dengan kepolisian (Mabes, poda, polres serta polsek), Kejaksaan dan Pengadilan, hal tersebut dapat dilihat pada gambar di bawah ini:

\section{Gambar 3}

Ilustrasi Kordinasi dengan Aparatus Penegak Hukum

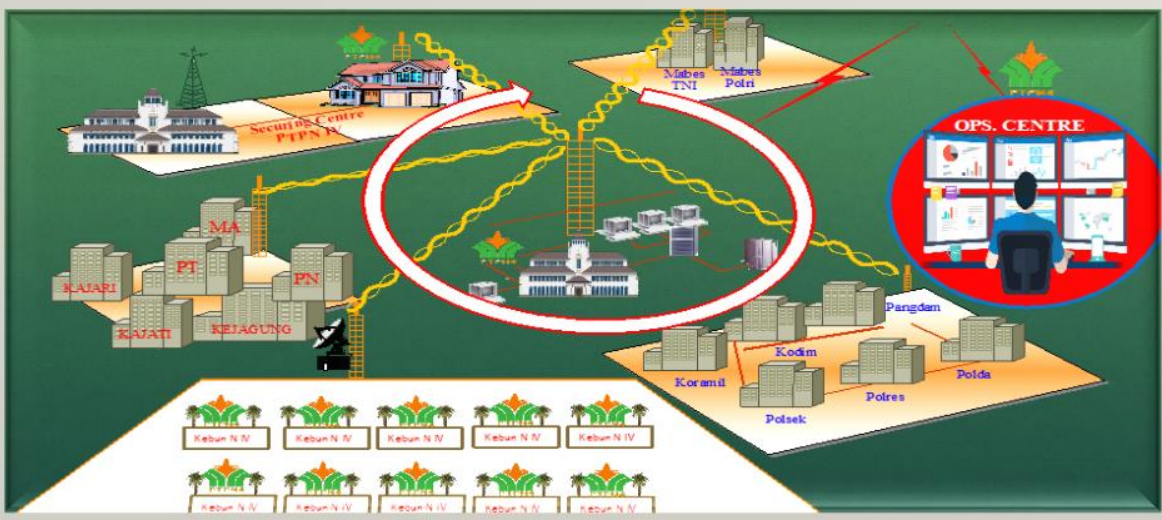

Sumber : Data Primer yang diolah dari PTPN VI, Maret 2020.

\section{c. Hambatan Budaya Hukum}

Adapun hambatan-hambatan dari sisi budaya hukum terhadap pengamanan aset kebun berupa TBS kelapa sawit milik PTPN IV, antara lain: ${ }^{54}$

1) "Ada dan terciptanya persengkokolan jahat yang terstruktur dan sistemik antara oknum-oknum pegawai PTPN IV dengan oknum penegak hukum dan instansi lainnya dalam wilayah PTPN IV;

2) Maraknya peredaran narkoba dan judi yang sudah berakar dan membudaya di area sekitar kebun PTPN IV;

3) Sistem pengamanan kebun/perusahaan yang tidak maksimal dan juga tidak sesuai standard pengamanan yang baku.

4) Pengkondisian keadaan keamanan seakan-akan aman terkendali akan tetapi hanya berdasarkan ABS / Asal Bapak Senang, bukan fakta di lapangan yang menciptakan efek domino.

5) Terlibatnya oknum karyawan internal PTPN IV, banyak disebabkan oleh: 
Fakultas Hukum Universitas Komputer Indonesia

Vol. 2 No. 2 Juli 2020

a) Kurangnya pengawasan dan evaluasi setiap karyawan terhadap SOP yang baku berdasarkan appraisal masing-masing individu staff dan karyawan itu sendiri.

b) Tidak adanya evaluasi kontrak kerja terhadap vendor perusahaan rekanan dalam bidang pengangkutan TBS yang seringkali ditenggarai terjadi tindak pencurian yang melibatkan vendor.

c) Dugaan penggunaan Narkoba oleh oknum staff dan karyawan di lingkungan perusahaan disinyalir dapat memicu terjadinya tindak kriminal pencurian TBS milik perusahaan.

6) Perusahaan kurang tegas dalam menindak pelaku tindak kejahatan pencurian TBS yang seringkali hanya mendapatkan vonis Tipiring (tindak pidana ringan) sehingga tidak pernah mendapatkan vonis yang berat di persidangan.

7) Alokasi dana Corporate Social Responsibility (CSR) yang kurang menyentuh hati masyarakat (tidak tepat sasaran) sekitar kebun PTPN IV, menjadikan keberadaan perkebunan tidak memberikan kontribusi yang positif terhadap masyarakat".

Dengan hambatan-hambatan yang kompleks tersebut, sulit untuk mengeluarkan PTPN IV dari pencurian TBS pada kebun-kebun perusahaan. Hal ini disebabkan budaya "pencuri" telah mengakar pada oknum-oknum staff dan pegawai/karyawan perusahaan. Sehingga mengakibatkan perusahaan mengalami kerugian yang signifikan sebesar Rp. 9,1 miliar per bulannya.

Dengan demikian, perlu untuk menerapkan Good Corporate Governance (GCG) dalam bidang pengamanan aset untuk meminimalkan pencurian TBS kelapa sawit tersebut. Prinsip-prinsip GCG yang harus diturunkan menjadi prinsip-prinsip pengamanan aset, yaitu: prinsip TIARF (Transparency, Independency, Accountability, Responsibility, dan Fairness). Prinsip-prinsip GCG yang diturunkan menjadi prinsip pengamanan aset adalah sistem keamanan terpadu. Sistem keamanan terpadu terdiri dari berbagai metode dan konsep pengamanan yang tidak hanya menggunakan hard skill tetapi juga menggunakan soft skill dibantu dengan penggunaan teknologi keamanan termodern dilandasi oleh pendekatan lokal yang terukur.

Adapun metode pelaksanaannya, yaitu: daya tangkal; daya deteksi; daya hambat; daya respon; dan daya tolak. Untuk melaksanakan metode-metode tersebut, PTPN IV sebaiknya melakukan pengamanan umum dan pengamanan tertutup. Pengamanan umum dapat disebut juga lidik terbuka, sedangkan pengamanan tertutup disebut juga lidik tertutup.

\section{Upaya PTPN IV Dalam Menerapkan GCG di Bidang Pengamanan Aset Pada PTPN IV Ditinjau Dari Sistem Hukum}

Adapun upaya PTPN IV dalam menerapkan GCG di bidang pengamanan aset untuk meminimalkan pencurian TBS kelapa sawit, sebagai berikut: ${ }^{55}$

\section{a. Upaya Substansi Hukum}

\section{Ibid.}


Vol. 2 No. 2 Juli 2020

Kebijakan Hukum Pidana biasa disebut juga dengan politik hukum pidana. Berbicara mengenai politik hukum pidana, maka tidak terlepas dari pembicaraan mengenai politik hukum secara keseluruhan karena hukum pidana adalah salah satu bagian dari ilmu hukum.

Adapun tahap-tahap upaya hukum menurut peraturan perundangundangan yang telah dilakukan PTPN IV untuk meminimalisir pencurian TBS pada kebun-kebun perusahaan, antara lain:

1) Menyerahkan oknum pelaku kepada pihak keamanan untuk didata apa-apa saja yang telah dicuri.

2) Pihak keamanan menyerahkan kepada pihak kepolisian untuk diproses lebih lanjut lagi.

3) Kemudian Direktur SDM dan Umum PT. Perkebunan Nusantara IV Medan Sumatera Utara memberikan Surat Kuasa Khusus kepada Kabag Hukum selaku penerima kuasa untuk melakukan Pelaporan /Pengaduan di Bareskrim Markas Besar Kepolisian Negara Republik Indonesia pada tanggal 8 Desember 2017.

4) Selanjutnya dari pihak kepolisian memberikan Surat Tanda Bukti Lapor (STBL) kepada Kabag Hukum PTPN IV selaku penerima kuasa dari Direktur SDM dan Umum PT. Perkebunan Nusantara IV Medan Sumatera Utara;

5) Tanda Bukti Lapor Nomor: TBL/937/XII/2017 Bareskrim, tanggal 8 Desember 2017 tentang Pelaporan Dugaan Tindak Pidana Memanen atau Memungut Hasil Perkebunan secara tidak sah sebagaima dimaksud dalam Pasal 107 huruf (d) Undang-Undang No. 39 Tahun 2014 tentang Perkebunan jo Pasal 55 KUHPidana;

6) Kemudian Bareskrim Polri melakukan gelar perkara kasus Pencurian di PT. Perkebunan Nusantara IV Medan Sumatera Utara, yang berpatokan kepada Hukum Acara Pidana dan ketentuan lainnya berdasarkan Perkap Kapolri.

Setelah dinyatakan tersangka oleh Kepolisian Negara Republik Indonesia, maka perlu dilakukan tindakan tegas baik berupa pemecatan atau pemutusan hubungan kerja (PHK) dan legal action berupa penangkapan dan/atau penahan terhadap Oknum Pejabat/Karyawan/Papam/BKO/TNI/Polri yang terlibat dalam kasus pencurian aset perkebunan di PT. Perkebunan Nusantara IV Medan Sumatera Utara.

Upaya paksa tersebut didasarkan kepada Tanda Bukti Lapor Nomor: TBL/937/XII/2017 Bareskrim, tanggal 8 Desember 2017 tentang Pelaporan Dugaan "Tindak Pidana Memanen atau Memungut Hasil Perkebunan Secara Tidak Sah" sebagaima dimaksud dalam Pasal 107 huruf (d) Undang-undang Nomor 39 Tahun 2014 tentang Perkebunan jo Pasal 55 KUHPidana.

Surat dari Kepala Badan Intelijen Keamanan Polri Nomor: B/2082/XII/2017/Baintelkam, tanggal 15 Desember 2017 perihal Hasil Penyelidikan terkait Pencurian Kelapa Sawit di PT. Perkebunan Nusantara IV Medan Sumatera Utara.

\section{Gambar 4}

Ilustrasi Output Penangan Pencurian dan Penggelapan TBS Kelapa Sawit Pada Kebun-Kebun PTPN IV 


\section{Res Nullius}

Vol. 2 No. 2 Juli 2020

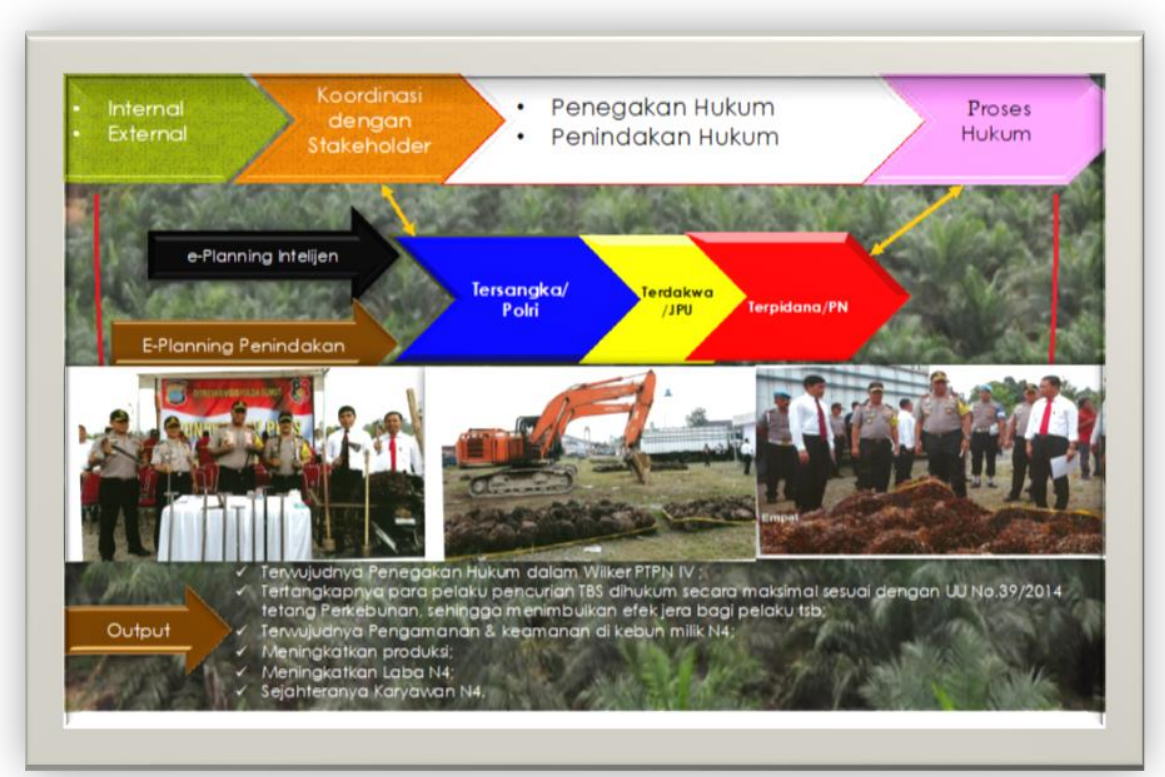

Sumber : Data Primer yang diolah dari PTPN VI, Maret 2020.

\section{b. Upaya Struktur Hukum}

Adapun upaya struktur hukum dari pihak PTPN IV untuk meminimalkan pencurian TBS pada kebun-kebun perusahaan, sebagai berikut:

1) Memasang alat tambahan keamanan di daerah-daerah rawan pencurian.

2) Menambah jumlah personil keamanan.

3) Memberdayakan Pamswakarsa di tengah lingkungan masyarakat yang ada di sekitar perkebunan.

4) Membuat parit-parit gajah dan membuat benteng di daerah yang berbatasan dengan desa tempat masyarakat tinggal dan tempat yang rawan dilakukan pencurian. Tujuannya untuk mempersulit pemindahan buah keluar arela perkebunan.

5) Melakukan blokade jalan dan memasang portal yang tujuannya untuk menyulitkan pelaku mengangkat atau membawa pergi hasil curiannya.

\section{c. Upaya Budaya Hukum}

Adapun upaya budaya hukum yang telah dilakukan oleh pihak PT.

Perkebunan Nusantara IV Medan Sumatera Utara adalah sebagai berikut :

1) Meningkatkan patroli keamanan kebun (patrol rutin satu kali satu hari menjadi tiga kali satu hari);

2) Mengkonsentrasikan pihak keamanan kebun pada tempat-tempat yang rawan terjadi pencurian;

3) Mengadakan hubungan sosial yang baik dengan masyarakat seperti mengadakan penyuluhan kepada masyarakat;

4) Pembinaan kehidupan rumah tangga yang selaras, seimbang dan serasi menuju pada kehidupan keluarga yang harmonis. 
Vol. 2 No. 2 Juli 2020

\section{KESIMPULAN \& SARAN}

\section{Kesimpulan}

Berangkat dari uraian-uraian tersebut di atas, maka dapat ditarik benang merah, sebagai berikut:

1. Penerapan Tata Kelola Perusahaan Yang Baik (Good Corporate Governance) dalam bidang pengamanan aset untuk meminimalisir pencurian Tandan Buah Segar (TBS) kelapa sawit di PTPN IV adalah dengan penggunaan alat berteknologi tinggi yang didukung dengan aplikasi "Smart Security of Integrity" atau "pengamanan teknologi terintegrasi". Penerapan "Smart Security of Integrity" ini dilaksanakan oleh petugas pengamanan dari PTPN IV itu sendiri. Sejak digunakannya metode "pengamanan teknologi terintegrasi" tersebut, maka hasil yang didapat: Pertama, dapat menciptakan iklim yang kondusif pada internal perusahaan. Kedua, penyediaan dan peningkatan kualitas pengamanan di area perkebunan. Ketiga, penyediaan fasilitas dan pembiayaan dalam membangun sistem pengamanan terpadu. Keempat, peningkatan kualitas serta penyediaan infrastruktur pengamanan dan keamanan.

2. Adapun hambatan dan upaya PTPN IV dalam bidang pengamanan aset untuk meminimalisir tindak pidana pencurian kelapa sawit dalam perspektif sistem hukum, sebagai berikut:

a. Hambatan-hambatan yang dihadapi, terdiri dari:

1) Hambatan substansi hukum, adanya Peraturan Mahkamah Agung No. 02 Tahun 2012 tentang Penyesuaian Batasan Tindak Pidana Ringan yang dapat digunakan, jika aparat penegak hukum tidak menggunakan ketentuan pasal UU Perkebunan, melainkan pidana umum dalam KUH.Pidana.

2) Hambatan struktur hukum, pada dasarnya pencurian-pencurian yang dilakukan diduga oleh oknum-oknum staff/pegawai/karyawan perusahaan sendiri yang kurang puas dengan kesejahteraan perusahaan atau dengan kata lain terjadi kesenjangan sosial antar para pegawai, sehingga membuka peluang untuk bekerjasama mencuri hasil kebun.

3) Hambatan budaya hukum, terciptanya persekongkolan jahat yang terstruktur dan sistematis antara oknum-oknum pegawai perusahaan dengan oknum aparat penegak hukum dan instansi lainnya dalam wilayah PTPN IV.

b. Upaya-upaya yang telah dilakukan, terdiri dari:

1) Upaya substansi hukum, dengan membuat laporan pidana dengan menggunakan ketentuan pidana dalam UU Perkebunan sebagai lex specialis terhadap pencurian hasil kebun sehingga Perma 02/2012 tidak dapat diterapkan.

2) Upaya struktur hukum, dengan menerapkan sistem pengamanan terpadu "Smart Security of Integrity" yang didukung dengan peralatan-peralatan canggih dan modern. 
Vol. 2 No. 2 Juli 2020

3) Upaya budaya hukum, melakukan pengkajian ulang terhadap kesejahteraan staff/pegawai/karyawan perusahaan agar tidak terjadi kesenjangan sosial, seperti: memberikan alokasi dana Corporate Social Responsibility (CSR) atau Program Tanggung Jawab Sosial dan Lingkungan (TJSL) perusahaan dengan mendahulukan kepentingan karyawan dan lingkungan sekitar.

Saran

Berangkat dari kesimpulan di atas, maka adapun saran yang dapat direkomendasikan dalam penelitian ini, yaitu :

1. Menerbitkan surat edaran dewan direksi dan sosialisasi secara berkala dan terstruktur kepada seluruh karyawan PT. Perkebunan Nusantara IV tentang tindakan tegas bagi oknum staff/pegawai/karyawan perusahaan yang telah terbukti telah melakukan tindakan kriminal dan/atau tindakan pidana pencurian dan penggelapan akan diberhentikan dengan tegas tanpa pesangon dan atau tunjangan lainnya.

2. Melakukan kajian ulang (re-view) terhadap SOP Security dan ploting anggota yang tepat dan sesuai dengan standard pengamanan yang benar (ahli dibidangnya), terhadap kontrak kerjasama dengan vendor-vendor ataupun pihak ketiga dalam hal pengangkutan (TBS) terintegrasi dengan system IT, sehingga menutup kemungkinan terjadinya kerja sama yang merugikan perusahaan dengan pihak-pihak baik internal maupun eksternal perusahaan dalam lingkunagan PT. Perkebunan Nusantara IV.

\section{DAFTAR PUSTAKA}

\section{Buku}

Ali, Zainuddin., Metode Penelitian Hukum, Jakarta : Sinar Grafika, 2009.

Agoes, Sukrisno., Etika Bisnis dan Profesi, Jakarta: Salemba Empat, 2011.

Bakkannnavar, Shankar M., Forensic Medicine and Toxicology: Practical Manual, New Delhi: Elsevier, RELX India Pvt.Ltd., 2018.

Bartens, K., Pengantar Etika Bisnis, Yogyakarta: Kanisius, 2002.

Bungin, Burhan., Penelitian Kualitatif : Komunikasi, Ekonomi, Kebijakan Publik, dan Ilmu Sosial Lainnya, Jakarta : Kencana, 2009.

Chazawi, Adami., Kejahatan Terhadap Harta Benda, Malang: Bayu Media, 2003.

Clarkson, Max B.E., ed. The Corporation and Its Stakeholders: Classic and Contemprorary Readings, Toronto : University of Toronto Press, 1998.

Crowe, Timothy D., Crime Prevention Through Environmental Design: Applications of Architectural Design and Space Management Concepts, $2^{\text {nd }}$ Edition, Boston, USA: Butterworth-Heinemann, 2000.

Crowter, Jonatahan (ed), Good Corporate Governance, Oxford Advanced Learners Dictionary, New York : Oxford University Press, 1995.

Darmawaty, Deni., Khomsiyah, dan Rika Gelar Rahayu, Hubungan Corporate Governance dan Kinerja Perusahaan, Bali, Denpasar: SNA VII, Desember 2004.

Darmawi, Asmaji., Antologi Administrasi Publik \& Pembangunan: Festschrift untuk Sjamsiar Sjamsuddin, Cet. Ke-1, Malang: UB Press, 2016. 
Vol. 2 No. 2 Juli 2020

Davies, A., A Strategic Approach to Corporate Governance, England: Gower Publishing Limited, 1999.

Djakti, Dorodjatun Kuncoro., Good Corporate Governance di Indonesia: Komisaris Independen Penggerak Praktik GCG di Perusahaan, Jakarta : Indeks, 2004.

Ediwarman, Monograf Metodologi Penelitian Hukum: Panduan Penulisan Skripsi, Tesis, dan Disertasi, Yogyakarta: Genta Publishing, 2016.

Echdar, Saban., dan Maryadi, Business Ethic and Entrepreneurship (Etika Bisnis \& Kewirausahaan), Yogyakarta: Deepublish, 2019.

Fajar, Mukti., dan Yulianto Achmad, Dualisme Penelitian Hukum-Normatif dan Empiris, Yogyakarta : Pustaka Pelajar, 2015.

Friedman, Andrew L., dan Samantha Miles, Stakeholders Theory and Practice, UK : Oxford University Press, 2006.

Friedman, Lawrence M., Sistem Hukum : Perspektif Ilmu Sosial, Bandung : Nusa Media, 2013.

Judith, Hennigfeld., The ICCA Handbook on Corporate Social Responsibility, John Wiley \& Sons, 2006.

Khairandy, Ridwan., dan Camelia Malik, Good Corporate Governance, Perkembangan Pemikiran dan Implementasinya di Indonesia dalam Perspektif Hukum, Yogyakarta: Kreasi Total Media, 2007.

Khairandy, Ridwan., Perseroan Terbatas Doktrin Peraturan Perundang-Undangan dan Yurisprudensi, Yogyakarta: Kreasi Total Media, 2009.

Kusumastuti, A. Dwi., Pengaruh Good Corporate Governance Terhadap Kinerja Perusahaan Pada Perusahaan-Perusahaan Manufaktur Yang Terdaftar di Bursa Efek Indonesia Tahun 2011, Surakarta: Universitas Surakarta, 2013.

Lipton, Philip., dan Abraham Herzberg, Understanding Company Law, Brisbane: The Law Book Company Ltd., 1992.

Lubis, M. Solly., Filsafat Ilmu dan Penelitian, Bandung : Mandar Maju, 1994.

Mahmoudi, Reza., dan Krzystof Iniewski (Editor), Low Power Emerging Wireless Technologies, New York: CRC Press, 2013.

Marzuki, Peter Mahmud., Penelitian Hukum, Jakarta : Prenada Media Group, 2007.

Moeljono, Djokosantoso., Good Corporate Culture Sebagai Inti Good Corporate Governance, Jakarta : Elex Media Komputindo, 2005.

Moffitt, Michael L., and Robert C. Bordone, eds., Handbook of Dispute Resolution Program on Negotiation/Jossey-Bass, 2005.

Muttaqien, Andi., dkk., Undang-Undang Perkebunan, Wajah Baru Agrarische Wet: Dasar dan Alasan Pembatalan Pasal-Pasal Kriminalisasi oleh Mahkamah Konstitusi, Cet. Ke-1, Jakarta: Elsam-Sawit Watch-Pilnet, April 2012.

Pamukcu, Sibel., dan Cheng, Liang., (Editor), Underground Sensing: Monitoring and Hazard Detection for Environment and Infrastructure, London Wall, UK: Elsevier, 2018.

Pelzer, Karl J., Sengketa Agraria : Pengusaha Perkebunan Melawan Petani, Pustaka Sinar Harapan, 1991.

Prasetyo, Teguh., dkk., Hukum dan Undang-Undang Perkebunan, Bandung : Nusamedia, 2013.

Prodjodikoro, Wirjono., Asas-Asas Hukum Pidana di Indonesia, Bandung : Eresco, 1989.

Reksodiputro, Mardjono., Kriminologi dan Sistem Peradilan Pidana, Jakarta : Pusat Pelayanan Keadilan dan Pengabdian Hukum, Universitas Indonesia, 1994.

Santoso, Topo., dan Eva Achjani Zulfa, Kriminologi, Cet. Ke-13, Jakarta : Rajawali Press, 2013. 
Vol. 2 No. 2 Juli 2020

Sikumbang, Jusmadi., Mengenal Sosiologi dan Sosiologi Hukum, Medan : Pustaka Press, 2010.

Smerden, Richard., A Practical Guide to Corporation Governance, $4 \mathrm{t}^{\mathrm{h}}$ Ed., London: Thomson Reuters (Legal) Limited, 2010.

Snoeyenbos, Milton., Robert Almeder, James Humber, Business Ethics, $3^{\text {th }}$ Ed., New York: Prometheus Books, 2001.

Soekanto, Soerjono., Penelitian Hukum Normatif : Suatu Tinjauan Singkat, Jakarta : Raja Grafindo Persada, 2001.

Sugiarto, Totok., Pengantar Kriminologi, Surabaya : Jakad Media Publishing, 2017.

Sutedi, Adrian., Good Corporate Governance, Jakarta: Sinar Grafika, 2011.

Suyono, Sri., Perlindungan Hukum Terhadap Karyawan Dalam Rancangan Merger Diantara BUMN), Program Pascasarjana Universitas Sumatera Utara, Medan, 2003.

Tjager, I Nyoman., Corporate Governance Tantangan dan Kesempatan Bagi Komunitas Bisnis Indonesia, Jakarta: Prenhallindo, 2003.

Tjokroamidjoyo, Bintaro., dan Mustofa Adijoyo, Teori dan Strategi Pembangunan Nasional, Jakarta : Hadi Masagung, 1998.

Tunggal, A. Wijaya., Internal Audit dan Good Corporate Governance, Jakarta: Erlangga, 2013.

Wagiran, Metodologi Penelitian Pendidikan : Teori dan Implementasi, Sleman : Deepublish, 2019.

Wuisman, JJ. M., Penelitian Ilmu-Ilmu Sosial, Asas-Asas, Jakarta : Penerbit Fakultas Ekonomi Universitas Indonesia, 1996.

Zakhem, Abe J., Daniel E. Palmer, and Mary Lyn Stoll, Stakeholder Theory: Essential Readings in Ethical Leadership and Management, Amherst, NY : Prometheus Books, 2008.

Zed, Mestika., Metode Penelitian Kepustakaan, Ed. Ke-2, Jakarta : Yayasan Obor Indonesia, Januari 2008.

\section{Karya Ilmiah dan Jurnal}

"Karang Mendapo Melawan Ketidakadilan", Elsam-Pilnet-Sawit Watch, 2012.

Anonymous, Seri Monograf 3, UNESCO Regional Office for Education in Asia and the Pacific.

Agustine, Oly Viana., "Putusan Mahkamah Konstitusi Dalam Pembangunan Ekonomi Nasional Pada Pemuliaan Tanaman dan Alat Berat (The Decision of the Constitutional Court on the National Economy Development on the Plant Breeding and Heavy Equipment)", Jurnal RechtsVinding Media Pembinaan Hukum Nasional Vol. 7, No. 1, April 2018.

Alhamra, Insan Thariq., dan Hermiyetti, "Analisis Pengaruh Good Corporate Governance dan Tingkat Profitabilitas Terhadap Pengungkapan Informasi Akuntansi (Studi Empiris Pada Top 50 Emiten Dengan Skor CG Tertinggi Hasil IICD Melalui Pendekatan ASEAN Corporate Governance Scorecard Periode 2012-2013), Prosiding Seminar Nasional INDOCOMPAC, Universitas Bakrie, Jakarta, dilaksanakan tanggal 2-3 Mei 2016.

Araujo, Elidio Dee., "Pengaruh Kepemimpinan Stratejik dan Corporate Culture Terhadap Kinerja Perusahaan Dengan Good Corporate Governance Sebagai Variabel Intervening (Suatu Studi Persepsi Manajer Pada Perusahaan Anggota Camara Comercia Indusria Timor Leste (CCI-TL)", Ph.D diss., Widya Mandala Catholic Universitas Surabaya, Surabaya, 2013. 
Vol. 2 No. 2 Juli 2020

Arbaina, Endang Siti., "Penerapan Good Corporate Governance Pada Perbankan Di Indonesia", Jurnal Akuntansi AKUNESA 1, No. 1, (2012).

Bone, Fandi La Ode., dan Sahrul Ponto, "Pengaruh Perusahaan dan Faktor Regulasi Terhadap Kualitas Implementasi Corporate Governance", Future: Jurnal Manajemen dan Akuntansi 4, No. 2, (2017): 178302.

Donaldson, Thomas., dan Lee E.Preston, "The Stakeholder Theory of the Corporation: Concepts, Evidence, Implications", Academy of Management Review, January 1995.

G. Suprayitno, dkk., "Internalisasi Good Corporate Governance Dalam Proses Bisnis: Laporan Corporate Governance Perception Index 2004", The Indonesian Institute for Corporate Governance, Jakarta, April 2005.

Iswandi dan Widya Rahmawati, "Evaluasi Pelaksanaan dan Penerapan Prinsip Dalam Pengelolaan Perusahaan Yang Baik (Good Corporate Governance) Pada PT. Aneka Tambang, Tbk", Binus Business Review Vol. 2 No. 1, (Mei 2011).

Kelvianto, Iestyn., dan Ronny H. Mustamu, "Implementasi Prinsip-Prinsip Good Corporate Governance Untuk Keberlanjutan Usaha Pada Perusahaan Yang Bergerak di Bidang Manufaktur Pengolahan Kayu”, Agora Vol. 6 No. 2, (2018).

Lestari, Tri Rini Puji., "Menyoal Pengaturan Konsumsi Minuman Beralkohol di Indonesia", Jurnal Aspirasi Vol. 7 No. 2, Desember 2016.

Maulida, Rizka., dkk., "Pengalihan Kewenangan Bapepam-LK Kepada Otoritas Jasa Keuangan Dalam Hal Pengawasan Transaksi Efek (Studi di Kantor Otoritas Jasa Keuangan Pusat)", Kumpulan Jurnal Mahasiswa Fakultas Hukum, (2015).

Merpati, Vega O., "Hak dan Kewajiban Perusahaan Terhadap Pekerja Yang Bekerja Melebihi Batas Waktu", Lex et Societatis Vol. II No. 8, Sep-Nov 2014.

Miraza, Bactiar Hassan., "Good Corporate Governance" Makalah disampaikan pada lokakarya Good Corpore Governance, kerjasama Program Pascasarjana Universitas Sumatera Utara, Program Pascasarjana Universitas Indonesia, Universitas of South Carolina, Bursa Efek Jakarta dan Bapepam, Medan, 2000.

Madari, Muhammad Soma Karya., "Penyesuaian Batasan Tindak Pidana Rirngan dan Jumlah Denda Dalam KUHP Terhadap Perkara Tindak Pidana Pencurian (Analisis Peraturan Mahkamah Agung No. 02 Tahun 2012 tentang Penyesuaian Batasan Tindak Pidana Ringan dan Jumlah Denda Dalam KUHP”, Fakultas Hukum UIKA Bogor.

Pandiangan, Sichmen., "Bentuk-bentuk Perlawanan Petani terhadap Negara", Jurnal Pemberdayaan Komunitas, Volume 5 No. 3.

PT. Perkebunan Nusantara IV, "Laporan Tahunan 2017”, PT. Perkebunan Nusantara IV, Medan, 2018.

Raharjo, Teguh Budi., "Good Corporate Governance (GCG) dan Pemahamannya di Dunia Bisnis", Permana 2, No. 1, (2010).

Riantono, I.E., "Pengelolaan Manajemen Modern Dalam Mewujudkan Good Corporate Governance : Optimalisasi Pencapaian Tujuan Perusahaan", Binus Business Review Vol. 5 No. 1, (Mei 2014).

Rohaeni, Eni Siti., dkk., "Uji Coba Penggunaan Microchip Sebagai Sistem Deteksi/Monitor Sapi Kembar di Kalimantan Selatan”, Seminar Nasional Inovasi Teknologi Pertanian, 2013.

Supatmi, "Corporate Governance dan Kinerja Keuangan", Jurnal Bisnis dan Ekonomi Vol. 14, (2007). 
Vol. 2 No. 2 Juli 2020

Syahidulhaq, Hafiidh As, Hafiddudin Hafiddudin, and Suci Aulia. "Sistem Keamanan Berbasis Alarm Ip Camera dengan Passive Infrared Receiver (Pir) Sensor dan SMS Gateway." Jurnal Elektro dan Telekomunikasi Terapan 3, No. 2 (2016).

Theberge, Leonard J., "Law and Economic Development", Journal of International Law and Policy, (Vol.9:231).

Toha, Suherman., dkk., "Laporan Akhir: Penelitian Masalah Hukum Tentang Penerapan Good Corporate Governance Pada Dunia Usaha", Pusat Penelitian dan Pengembangan Hukum Badan Pembinaan Hukum Nasional Departemen Hukum dan HAM RI, Jakarta, 2015.

Warman, Edi., "Analisis Yuridis Mengenai Tindak Pidana Pencurian Aset Perkebunan PTPN II Kebun Tanjung Garbus-Pagar Merbau Lubuk Pakam Dalam Perspektif Kriminologi”, Jurnal Mahupiki Vol. 2 No. 1, (2014).

Wibowo, Edi., "Implementasi Good Corporate Governance di Indonesia", Jurnal Ekonomi dan Kewirausahaan Vol. 10 No. 2, Oktober 2010.

Yudanto, Noor., dan M. Setyawan Santoso, "Dampak Krisis Moneter Terhadap Sektor Riil”, Buletin Ekonomi Moneter dan Perbankan, September 1998.

\section{Media Massa \& Internet}

Anonymous, "Risk Calculation Worksheet - Calculating Risk Using GAR Model (GreenAmbre-Red)",

https://www.dco.uscg.mil/Portals/9/DCO\%20Documents/National\%20Strike\%20 Force/foscr/ASTFOSCRSeminar/Presentations/Safety/ORM-

GAR.pdf?ver=2017-09-14-144539-427., diakses pada hari Jumat, tanggal 27 Maret 2020.

Berita RRI Online, "PTPN IV Rugi Hingga Rp. 15 Milyar Akibat Pencurian TBS", http://rri.co.id/post/berita/498585/daerah/akibat_pencurian_tbs_ptpn_iv_rugi_hin gga_rp15_milyar.html., diakses pada hari Rabu, tanggal 04 Maret 2020.

Friedman, Milton., "The Social Responsibility of Business is to Increase its Profits", The New York Times Magazine, tanggal 13 September 1970.

Harian Republika, "Pemerintah Perlu Beri Insentif Untuk Produksi Minyak Curah", diterbitkan Senin, 07 Oktober 2019.

Indonesia.co.id, "Membangun Industri Sawit Berkelanjutan", https://indonesia.go.id/narasi/indonesia-dalam-angka/ekonomi/membangunindustri-sawit-berkelanjutan., diakses Senin, 18 Mei 2020.

Indosecurity.net, "Pepper Spray", http://indosecurity.net/jual-pepper-spray-semprotanmerica-gas-air-mata-semprotan-cabai., diakses pada hari Kamis, tanggal 26 Maret 2020.

IndoSecuritySystem, "Salto Luncurkan Gembok Elektronik XS4 GEO", https://www.indosecuritysystem.com/read/access_control/2017/04/12/1726/saltoluncurkan-gembok-elektronik-xs4-geo., diakses pada hari Kamis, tanggal 26 Maret 2020.

Website Resmi Gabungan Pengusaha Kelapa Sawit Indonesia (Gapki), "Memecah Rekor: Ekspor Minyak Sawit 2017 Tembus USD. 22,9 Miliar", https://gapki.id/news/4129/memecah-rekor-ekspor-minyak-sawit-2017-tembusus-229-miliar., diakses Senin, 18 Mei 2020.

Website Resmi KBBI Online, "Pengamanan", https://kbbi.web.id/aman., diakses pada hari Selasa, tanggal 08 Oktober 2019.

Website Resmi Okezone.com., "Bappenas: BUMN Harus Dikelola Dengan Prinsip Korporasi”, 
Vol. 2 No. 2 Juli 2020

https://economy.okezone.com/read/2016/04/14/320/1362771/bappenas-bumnharus-dikelola-dengan-prinsip-korporasi., diakses pada hari Senin, tanggal 17 Februari 2020.

\section{Perundang-Undangan}

Undang-Undang No. 1 Tahun 1946 tentang Kitab Undang-Undang Hukum Pidana (KUHP).

Undang-Undang No. 8 Tahun 1981 tentang Hukum Acara Pidana (KUHAP).

Undang-Undang No. 17 Tahun 2003 tentang Keuangan Negara.

Undang-Undang No. 19 Tahun 2003 tentang Badan Usaha Milik Negara.

Undang-Undang No. 1 Tahun 2004 tentang Perbendaharaan Negara.

Undang-Undang No. 40 Tahun 2007 tentang Perseroan Terbatas.

Peraturan Pemerintah RI No. 45 Tahun 2005 tentang Pendirian, Pengurusan, Pengawasan, dan Pembubaran Badan Usaha Milik Negara.

Peraturan Pemerintah RI No. 72 Tahun 2014 tentang Penambahan Penyertaan Modal Negara RI ke Dalam Modal Saham Perusahaan (Persero) PT. Perkebunan Nusantara III.

Peraturan Pemerintah No. 72 Tahun 2016 tentang Perubahan Atas Peraturan Pemerintah No. 44 Tahun 2005 tentang Tata Cara Penyertaan dan Penatausahaan Modal Negara Pada Badan Usaha Milik Negara dan Perseroan Terbatas.

Peraturan Menteri Keuangan RI No. 78/PMK.06/2014 tentang Tata Cara Pelaksanaan Pemanfaatan Barang Milik Negara.

Peraturan Menteri Negara BUMN RI No. PER-05/M-MBU/2008 tentang Pedoman Umum Pelaksanaan Pengadaan Barang dan Jasa Badan Usaha Milik Negara.

Peraturan Menteri Negara BUMN No. PER-01/MBU/2011 tentang Penerapan Tata Kelola Perusahaan Yang Baik (Good Corporate Governance) Pada Badan Usaha Milik Negara (BUMN).

Peraturan Menteri Negara BUMN No. PER-01/MBU/2012 tentang Persyaratan dan Tata Cara Pengangkatan dan Pemberhentian Anggota Direksi BUMN.

Keputusan Menteri Badan Usaha Milik Negara No. KEP-117/M-MBU/2002 tentang Penerapan Praktek Good Corporate Governance pada Badan Usaha Milik Negara (BUMN).

Keputusan Sekretaris Kementerian Negara BUMN No. SK-16/S-MBU/2012 tentang Indikator/Parameter Penilaian dan Evaluasi atas Penerapan GCG.

Anggaran Dasar Perusahaan PTPN IV.

Keputusan Bersama Dewan Komisaris dan Direksi PT. Perkebunan Nusantara IV No. DK-03/KPTS/IV/2019 dan No. 04.01/KPTS/07/IV/2019 tentang Pemmberlakuan Pedoman Perilaku (Code of Conduct).

Keputusan Bersama Dewan Komisaris dan Direksi PT. Perkebunan Nusantara IV No. DK/18/KPTS/2016 dan No. 04.03/02/KPTS/2016 tentang Pemberlakuan Infrastruktur Good Corporate Governance PT. Perkebunan Nusantara IV.

Prosedur Tetap PTPN IV No. 04.13/Protap/01/X/2018 tentang Pengamanan Terpadu Aset Unit Usaha PT. Perkebunan Nusantara IV.

\section{Putusan Pengadilan}

Laporan No. TBL/937/XII/2017 Bareskrim, tertanggal 08 Desember 2017 tentang Pelaporan Dugaan Tindak Pidana Memanen Atau Memungut Hasil Perkebunan Secara Tidak Sah sebagaimana dimaksud dalam Pasal 107 hruuf d UndangUndang No. 39 Tahun 2014 tentang Perkebunan Jo. Pasal 55 KUH.Pidana. 


\section{Res Nullius}

Fakultas Hukum Universitas Komputer Indonesia

Vol. 2 No. 2 Juli 2020

Hasil Penyelidikan Kabaintelkam Mabes Polri terhadap Laporan Intelijen No. R/LI01/XI/2017/Dit.Sosbud, tertanggal 19 November 2017 Terkait Pencurian Kelapa Sawit di PTPN IV Sumut.

Putusan Mahkamah Konstitusi RI No. 48/PUU-XI/2013 tertanggal 18 September 2014. Putusan Mahkamah Konstitusi RI No. 62/PUU-XI/2013 tertanggal 03 Februari 2014.

Putusan Mahkamah Konstitusi No. No. 138/PUU-XIII/2015. 